\title{
Role of Corticotropin-releasing Factor in Gastrointestinal Permeability
}

\author{
Bruno K Rodiño-Janeiro, Carmen Alonso-Cotoner, ${ }^{*}$ Marc Pigrau, Beatriz Lobo, María Vicario, and Javier Santos \\ Neuro-Immuno-Gastroenterology Group, Digestive Diseases Research Unit, Gastroenterology Department, Hospital Universitari Vall d'Hebron, \\ Vall d'Hebron Research Institute; and Department of Medicine, Universitat Autònoma de Barcelona, Centro de Investigación Biomédica en Red \\ de Enfermedades Hepáticas y Digestivas (Ciberehd), Barcelona, Spain
}

\begin{abstract}
The interface between the intestinal lumen and the mucosa is the location where the majority of ingested immunogenic particles face the scrutiny of the vast gastrointestinal immune system. Upon regular physiological conditions, the intestinal microflora and the epithelial barrier are well prepared to process daily a huge amount of food-derived antigens and non-immunogenic particles. Similarly, they are ready to prevent environmental toxins and microbial antigens to penetrate further and interact with the mucosal-associated immune system. These functions promote the development of proper immune responses and oral tolerance and prevent disease and inflammation. Brain-gut axis structures participate in the processing and execution of response signals to external and internal stimuli. The brain-gut axis integrates local and distant regulatory networks and supersystems that serve key housekeeping physiological functions including the balanced functioning of the intestinal barrier. Disturbance of the brain-gut axis may induce intestinal barrier dysfunction, increasing the risk of uncontrolled immunological reactions, which may indeed trigger transient mucosal inflammation and gut disease. There is a large body of evidence indicating that stress, through the brain-gut axis, may cause intestinal barrier dysfunction, mainly via the systemic and peripheral release of corticotropin-releasing factor. In this review, we describe the role of stress and corticotropin-releasing factor in the regulation of gastrointestinal permeability, and discuss the link to both health and pathological conditions.
\end{abstract}

\section{(J Neurogastroenterol Motil 2015;21:33-50)}

Key Words

Corticotropin-releasing factor; Inflammation; Permeability; Stress

Received: July 17, 2014 Revised: October 6, 2014 Accepted: October 7, 2014

(c) This is an Open Access article distributed under the terms of the Creative Commons Attribution Non-Commercial License (http://creativecommons. org/licenses/by-nc/3.0) which permits unrestricted non-commercial use, distribution, and reproduction in any medium, provided the original work is properly cited.

*Correspondence: Carmen Alonso-Cotoner, MD, PhD

Neuro-Immuno-Gastroenterology Group, Digestive Diseases Research Unit, Gastroenterology Department, Hospital Universitari Vall d'Hebron, Vall d' Hebron Research Institute, Paseo Vall d' Hebron 119-129, 08035, Barcelona 08022, Spain

Tel: +34-93-4894035, Fax: +34-93-4894032, E-mail: caralons@vhebron.net

Bruno K Rodiño-Janeiro and Carmen Alonso-Cotoner contributed equally to this work.

Financial support: This work supported in part by the Fondo de Investigación Sanitaria and Ciberehd, Instituto Carlos III, Subdirección General de Investigación Sanitaria, Ministerio de Ciencia e Innovación and Programa de Especialización e Infraestructuras Internacionales 2012 (EIC-EMBL-2011-0070, Bruno K Rodiño-Janeiro; PI12/00314, Carmen Alonso-Cotoner; CM08/00229, Beatriz Lobo; CM10/00155, Marc Pigrau; CP10/00502, PI13/00935 and The Rome Foundation Award 2013, María Vicario; PI11/00716 \& CB06/04/0021, Javier Santos).

Conflicts of interest: None.

Author contributions: Bruno K Rodiño-Janeiro and Carmen Alonso-Cotoner wrote the paper; Beatriz Lobo and Marc Pigrau reviewed scientific literature and collected data; and María Vicario and Javier Santos gave clinical advice and critically reviewed the manuscript. All authors discussed the results and commented on the manuscript at all stages

ORCID: Bruno K Rodiño-Janeiro, http://orcid.org/0000-0002-0633-6774; Carmen Alonso-Cotoner, http://orcid.org/0000-0002-3483-2919; Marc Pigrau, http://orcid.org/0000-0001-6801-3017; Beatriz Lobo, http://orcid.org/0000-0003-3391-7125; María Vicario, http://orcid.org/0000-0001-9622-3185; Javier Santos, http://orcid.org/0000-0002-4798-5033. 
Official abbreviations according to UPHARM guideline were used in this review series.

$\mathrm{CRF}$, corticotrophin-releasing factor

$\mathrm{CRF}_{1}$, corticotrophin-releasing factor receptor 1

$\mathrm{CRF}_{2}$, corticotrophin-releasing factor receptor 2

\section{Introduction}

The epithelium that lines our digestive tract harbors 100 trillion bacteria ${ }^{1}$ and mediates our relationship to the world outside. Our intestine is constantly exposed to a wide variety of immunogenic particles and microorganism-derived antigens. Its surface area is large enough to process over 50 tons of food in a lifetime. Intestinal and microbial components are strongly linked to each other and represent the most important barrier to limit luminal antigens from travelling across and reach the mucosal-associated immune system. They also play a critical role in training and modulating our immune system, helping it to distinguish between friend and foe. ${ }^{2,3}$ The absence of constructive engagement between microbes and intestinal mucosa may render epithelial barrier more permeable, allowing it to be breached. When this happens, resident cells become over-activated, and a cascade of pro-inflammatory signals is initiated. ${ }^{4,5}$ Altered intestinal permeability has large implications for human health, being involved in the origin and development of many digestive and non-digestive diseases. However, up to date, it is not clear whether intestinal barrier dysfunction is a primary event, an epiphenomenon or a consequence in the pathogenesis of these disorders.

The regulation of intestinal permeability involves terminals from ascending and descending pathways from the autonomic nervous system and the central nervous system, the hypothalamic pituitary-adrenal axis, and the enteric nervous system as well. The vast and versatile array of bidirectional and integrative communications between the brain and the gut allows the brain to respond to internal and external signals and, in return, to modify the autonomic and enteric nervous systems to keep intestinal permeability tight.

Physical and psychological stresses represent convincing evidence of the influence of the brain-gut axis on the intestinal barrier function. In fact, stress has been associated with reactivation of inflammatory and functional gastrointestinal disorders mainly through disruption of the intestinal barrier ${ }^{6}$ in both human and animal models. The stress response is vehiculated via 2 main systems: the sympatho-adrenomedullary system and the hypothalamic pituitary-adrenal axis. Stress stimulates the parvocellular neurons in the paraventricular nucleus of the hypothalamus to se- crete corticotropin-releasing factor (CRF), and arginine vasopressin. CRF promotes the synthesis and release of adenocorticotropic hormone in the anterior pituitary. The adenocorticotropic hormone, in turn, activates the adrenal cortex to induce a temporary rise in blood levels of cortisol and corticosterone ${ }^{7}$ and also the release of catecholamines by the adrenal medulla. It has been believed for a long time that central secretion of CRF was the main and unique mediator of the majority of the endocrine, behavioral and gastrointestinal changes induced by stress. ${ }^{8}$ However, we will show that peripheral release of CRF also plays a key role in the regulation of gastrointestinal permeability, and discuss the link to both health and pathological conditions.

\section{Intestinal Permeability}

The intestinal mucosal barrier includes several consecutive layers, from the outermost microbiota, through the external mucus, the epithelium, and down to the innermost lamina propria.' The epithelial layer is described as a continuous polarized monolayer of columnar cells that separates the intestinal lumen from the internal milieu. Aside from epithelial cells, a variety of different cell types are also intermingled with enterocytes, including goblet cells, Paneth cells, enteroendocrine cells, and M cells. Within the lamina propria we can find blood and lymph vessels, and a plethora of distinct immune cells such as plasma cells, lymphocytes, macrophages, eosinophils, mast cells, dendritic cells, and a significant number of intrinsic and extrinsic nerve terminals. ${ }^{10}$ All of these components are exquisitely reactive and adaptive and display critical effector and modulatory functions. These functions are relevant for the control of inflammation, absorption and secretion, transport of macromolecules, and metabolic processes. ${ }^{11}$ Moreover, most of the cellular components have been shown to express receptors for CRF. ${ }^{12,13}$ But the job of the intestinal barrier now appears to be far more nuanced and complex as it communicates multidirectionally with the immune system and the microbes. Communication is developed through the release of an extensive array of chemical mediators, namely neuropeptides, neurohormones, neurotransmitters, cytokines, chemokines, growth factors, and other regulatory molecules. ${ }^{14,15}$

Enterocytes are tightly bonded to each other sealing the paracellular space through the apical junctional complex, composed of tight junctions (TJs), adherens junctions, and desmosomes. ${ }^{16}$ The transmembrane TJ proteins occludin and claudins form complex protein systems, which interact with zonula occludens proteins that bind to the actin cytoskeleton. When actin contracts, 
it leads to increased permeability to electrolytes and small molecules. ${ }^{17}$ The paracellular space is not fully impermeable to molecules and antigens, allowing a controlled amount of small particles (less than 400 daltons) to penetrate across to reach the lamina propria, a phenomenon that plays a key role in the induction of immune tolerance. This passage of molecules also takes place through the transcellular pathway via endocytosis or exocytosis. ${ }^{18}$ Disruption of the intestinal barrier leads to uncontrolled flux of luminal antigens and possibly microbes across the epithelium, which may trigger immune activation and sepsis, and also lead to the development of chronic inflammation in the gut. ${ }^{6,1920}$ Therefore, the tight regulation of intestinal permeability emerges as a central mechanism to prevent inflammatory diseases. Numerous pathogens and toxins, hormones and neurotransmitters, and gastrointestinal and non-gastrointestinal diseases have been associated with an augmented intestinal permeability. ${ }^{21}$ Among them, stress hormones and neurotransmitters have been consistently shown to modulate ion and water secretion, intestinal permeability, mucus secretion, and also intestinal flora. ${ }^{22-25}$

\section{Stress-induced Intestinal Barrier Dysfunction: Role of Corticotropin- releasing Factor and Related Peptides}

Stress represents a threat to the internal homeostasis that initiates a systemic coordinated response driven by the autonomic, endocrine, and immune systems to maintain stability. CRF and other members of the CRF signaling family, including urocortin (Ucn) 1, Ucn2, and Ucn3, are the best known and most important neuroendocrine mediators of the stress response. ${ }^{26,27}$ Central release of $\mathrm{CRF}$ and urocortins mediates autonomic, hormonal, and behavioural responses to stress and at the gastrointestinal tract, stimulates the enteric nervous system to modulate gastrointestinal motility and secretion. ${ }^{28-30}$ In addition, immune cells, regional sensory and sympathetic nerves, enterochromaffin cells, and enteric cells release CRF and urocortins within the gastrointestinal $\operatorname{tract}^{28}$ to modulate mucosal function and gastrointestinal motility. ${ }^{29}$

Different type of stress, acute or chronic, physical or psycho-
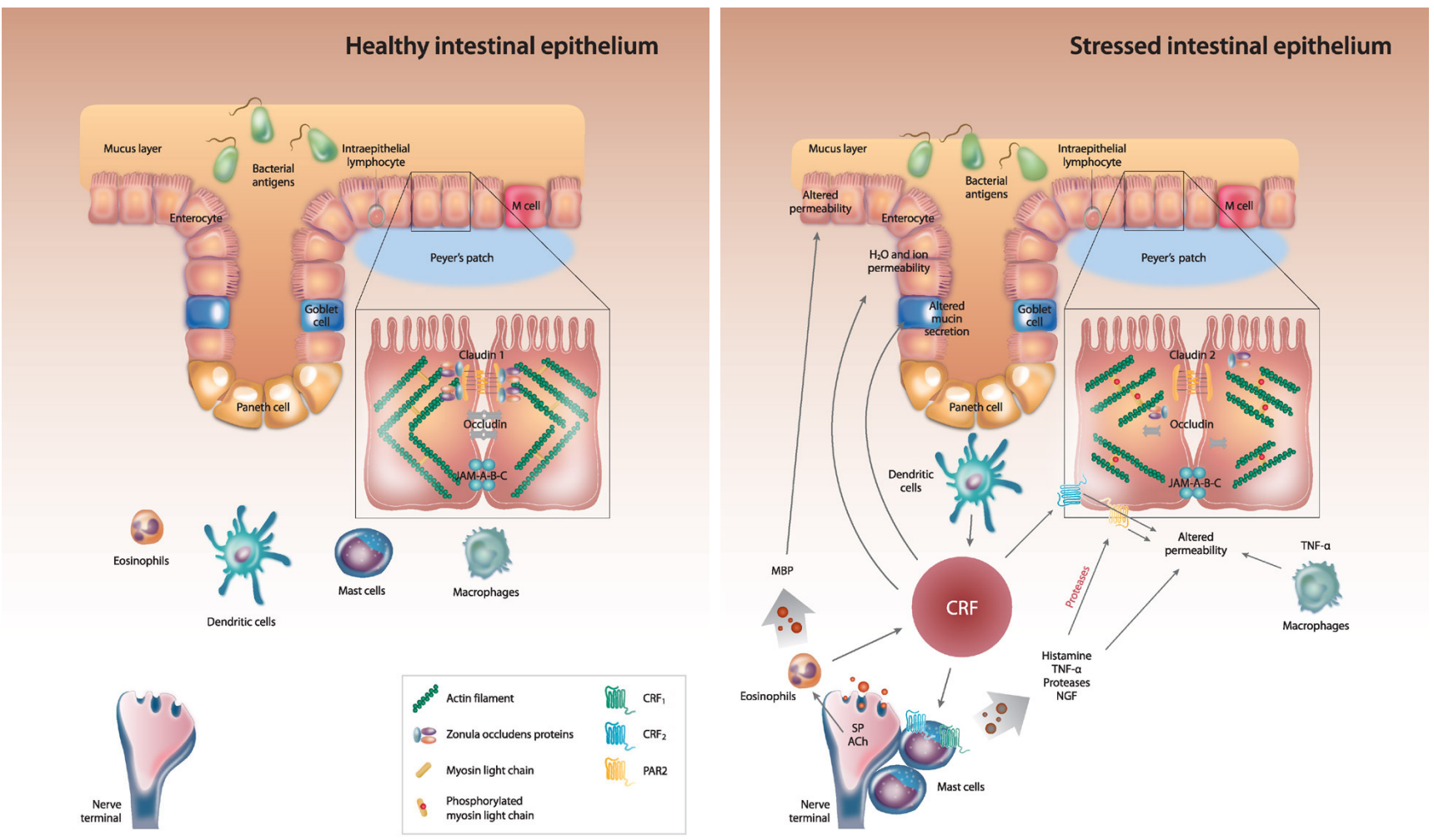

Figure. Corticotropin-releasing factor actions on gastrointestinal permeability under stress conditions. JAM-A-B-C, junctional adhesion molecule A-B-C; SP, substance $\mathrm{P}$; ACh, acetylcholine; $\mathrm{MBP}$, major basic protein; $\mathrm{CRF}$, corticotropin- releasing factor; $\mathrm{CRF}_{1}, \mathrm{CRF}$ receptor $1 ; \mathrm{CRF}_{2}, \mathrm{CRF}$ receptor 2; PAR2, protease activated receptor 2. 
logical, have been shown to influence properties of the intestinal barrier function, including ion and water secretion, intestinal permeability, mucus secretion, and also intestinal flora in both human and animal models. ${ }^{6,31-35}$ Similarly, both central and peripheral administration of exogenous $\mathrm{CRF}$ have been shown to mimic the effects of acute stress in the gastrointestinal tract inducing mucin release, ${ }^{36}$ and increasing ion and water secretion and intestinal permeability. ${ }^{37,38}$ Figure summarizes the main effects of stress on the intestinal barrier and the role of CRF in gastrointestinal permeability.

\section{Mucus Production and Release}

The intestinal mucosal surface is covered by a layer of mucus gel containing antibacterial peptides and digestive enzymes. ${ }^{39,40}$ Mucus protects the epithelial lining from adhesion and invasion by attacking microorganisms, and other antigens present in the intestinal lumen. ${ }^{41}$ Mucus is produced by goblet cells, which express the CRF receptor $1\left(\mathrm{CRF}_{1}\right) .{ }^{42}$ Stress has been shown to increase mucin release in colonic explants from rats submitted to immobilization, and to enhance rat mast cell protease II and prostaglandin E2 secretion. Intravenous or intracerebral injection of $\mathrm{CRF}$ in non-stressed rats reproduced stress-associated changes whereas administration of the $\mathrm{CRF}$ antagonist $\alpha$-helical-CRF ${ }_{9-41}$ or the mast cell stabilizer lodoxamide inhibited them. ${ }^{36}$ In addition, those changes were abolished in mast-cell deficient mice, highlighting the key role of the CRF-mast cell axis in stressmediated mucin release. ${ }^{43}$ On the contrary, rats submitted to chronic stress display mucus depletion and reduced number of goblet cells in the distal colon in association with increased bacterial adhesion and penetration into enterocytes, ${ }^{44,45}$ what could represent a step towards intestinal barrier dysfunction.

\section{Ion and Water Secretion}

Ion and water secretions also help to prevent the adhesion of pathogens and noxious substances to the mucosal surface, and dilute and flush out them down the gut to minimize their penetration to the lamina propria. Convergent evidences from studies in animal models indicate that both water and ion secretions increase in the intestinal tract in response to acute and chronic stress $^{24,46}$ and in response to peripheral administration of $\mathrm{CRF}^{47}$ whereas selective $\mathrm{CRF}_{1}$ receptor agonists prevent this response to stress. ${ }^{48,49}$ Increased baseline short-circuit current (Isc), indicative of enhanced anion secretion, was found in the jejunum of WistarKyoto rats submitted to restraint stress or cold restraint stress when compared to non-stressed rats. This increase in Isc was mediated by chloride anion secretion because replacement of the buffer by chloride free solution normalized $I s c$ values. ${ }^{50}$ Later, Santos et $\mathrm{al}^{37,51}$ reproduced the results using a model of repetitive exposure to water avoidance stress (WAS) and found that peripheral CRF reproduced stress-induced rat jejunal and colonic epithelial barrier dysfunction via cholinergic and adrenergic nerves, and mast cells. More recently, long-term crowding exposure, a model of psychosocial stress, has been shown to increase baseline $I s c$ in both the jejunum and the colon compared to non-stressed animals. ${ }^{52}$ Interestingly, colonic tissues from stressed rats exhibited a reduced $I s c$ response to the addition of cholinergic agonists and $\mathrm{CRF}$, suggesting an impaired secretory response to incoming stressful stimuli. Mitochondrial activity was disturbed throughout the intestine, although mitochondrial response to $\mathrm{CRF}$ was preserved. These changes were associated with an increased expression of $\mathrm{CRF}_{1}$ receptor in the colon of stressed rats and colonic hyperalgesia. ${ }^{53}$ Several other studies using various stress models have reproduced the elevation of Isc in the colon and ileum of rodents and showed the involvement of CRF receptors. $^{24,33,45,50,54-56}$

Both the acute intraperitoneal administration of $\mathrm{CRF}$ and chronic peripheral administration of $\mathrm{CRF}$, the selective $\mathrm{CRF}_{1}$ receptor agonist stressin- 1 and the selective $\mathrm{CRF}_{2}$ receptor ligand, $\mathrm{Ucn} 3$, increase the basal rat colonic $I s c{ }^{33,57}$ Therefore, a role for both $\mathrm{CRF}$ receptor subtypes in this alteration is suggested, although the response is not reduced by the selective $\mathrm{CRF}_{2}$ receptor antagonist antisauvagine. ${ }^{57}$ Furthermore, elevated baseline Isc has been also observed in the jejunum of early-weaned pigs, while activation of mast cells and CRF induced elevations in Isc in the pig jejunum mounted in Ussing chambers. This elevation in Isc was inhibited using mast cell protease inhibitors. ${ }^{58}$ Experiments using selective $\mathrm{CRF}$ receptor antagonists reveal that $\mathrm{CRF}_{1}$ receptor activation mediates barrier dysfunction and hypersecretion in the porcine intestine in response to early life stress. $^{58}$

Apart from ex vivo and in vivo studies, convincing evidence for a direct effect of CRF peptides on intestinal epithelial secretory response comes from in vitro work showing a consistent increase in Isc induced by CRF in the rat colon. ${ }^{33,37,59}$ Interestingly, maximal Isc increments were obtained with sauvagine, a CRF agonist with high affinity to both CRF receptors, at doses 200-1000 fold lower than $\mathrm{CRF}$, suggesting a predominant $\mathrm{CRF}_{2}$ receptor effect. ${ }^{59}$ In addition, the effect of peripheral CRF on Isc increase in rat colonic tissue implicates mast cells, and nicotinic and muscarinic receptors, as established by the pharmacological blockade 
of specific receptors and the use of mast cell deficient rats. ${ }^{37,57}$ Other studies performed in the guinea-pig support the ample distribution of $\mathrm{CRF}_{1}$ receptor, but not $\mathrm{CRF}_{2}$ receptor throughout the myenteric and submucosal plexuses of the gastrointestinal tract. ${ }^{60}$ However, all CRF and Ucn1, Ucn2, and Ucn3 were able to increase the excitability of neurons from the enteric nervous system in vitro. ${ }^{61}$

Experimental studies in humans reveal that acute physical or psychological stress modulate the intestinal barrier. More than 20 years ago, Barclay and Turnberg et al, ${ }^{62,63}$ using segmental perfusion techniques in the human jejunum, showed that acute stress reduced net water absorption or increased secretion, supporting the role of the central and the autonomic nervous system in the control of intestinal function. In particular, a reduction in water absorption coupled with net sodium/chloride secretion was observed in healthy subjects subjected to psychological stress induced by dichotomous listening. ${ }^{62,63}$ Later, Santos et $\mathrm{al}^{64}$ showed that cold pain stress increased jejunal water secretion in healthy subjects and in patients with food allergy. These observations have been confirmed and extended recently: using the cold pressor test. The increase in intestinal water secretion during cold pain stress was higher in healthy female volunteers with lower background stress levels, yet blunted in those with elevated background stress. ${ }^{65}$ These results suggest that chronic life stress could lead to the loss of regulatory mechanisms in healthy individuals, as previously described in the jejunum of chronic stressed rats after neural stimulation. ${ }^{50} \mathrm{CRF}_{1}$ receptor is expressed throughout the gastrointestinal tract in healthy subjects, and located in the lamina propria, mostly in macrophages, epithelial cells and enteric neurons, with the highest levels in the ileum and rectum and the lowest level in the colon. ${ }^{66} \mathrm{CRF}_{2}$ receptors are located in the lamina propria and in the epithelial cells of the distal/sigmoid biopsy samples in healthy subjects. ${ }^{67}$ In contrast to animal studies, the addition of CRF to human colonic biopsies from healthy individuals mounted in Ussing chambers did not show any effect on $I s c{ }^{68}$

\section{Permeability}

Numerous studies demonstrate the enhancement of intestinal permeability by acute and chronic stressors. In rodents, acute or subchronic stressors, including restraint stress, cold restraint stress, WAS, mild noise stress, and mixed restraint and acoustic stress, increased tissue conductance, and the fluxes of ${ }^{3} \mathrm{H}$ mannitol, ${ }^{51}$ Cr-labeled EDTA, horseradish peroxidase, in the jejunum, ileum, and colon. ${ }^{32,50,54,69-72}$ These results indicate the abil- ity of stress to modulate paracellular and transcellular transport of ions, and small and large macromolecules. Multiple mechanisms have been invocated to explain stress-mediated transport abnormalities. The list includes acetylcholine release, histamine, glucagon-like peptide-2, myosin light chain kinase, cytokines such as interferon- $\gamma$, interleukin (IL)-4 and IL-13, and mast cell activation, among the most relevant. ${ }^{32,61,71,73-75}$ Moreover, increased intestinal permeability, measured by lactulose, mannitol and sucralose ratios, was found in rats' small intestine, following acute swimming stress. ${ }^{23}$ This increase was glucocorticoid-mediated because adrenalectomy and pharmacologic blockade of glucocorticoid receptors inhibited the response, and dexamethasone increased gastrointestinal permeability in control rats. ${ }^{23}$

Similarly, rats models of chronic stress (maternal deprivation, ${ }^{55,77-79} \mathrm{WAS}^{45}$ and crowding stress ${ }^{52}$ ) also show increased ionic permeability, and macromolecular permeability throughout the intestine. The increase was mediated partly by mechanisms including, muscarinic and nicotinic pathways, activation and number of mast cells and the release of nerve growth factor. ${ }^{79}$ Stress-induced enhancement of colonic permeability was mimicked by exogenous administration of $\mathrm{CRF},{ }^{33}$ and abolished by pretreatment with the peripheral administration of the non-selective $\mathrm{CRF}$ antagonists astressin or $\boldsymbol{\alpha}$-helical $\mathrm{CRF}_{9-41}{ }^{37,55,80}$ Likely, the selective $\mathrm{CRF}_{1}$ receptor agonist, cortagine, ${ }^{48}$ the selective $\mathrm{CRF}_{1}$ receptor antagonist, SSR-125543, ${ }^{80}$ and the selective $\mathrm{CRF}_{2}$ receptor antagonist, antisauvagine- $30,{ }^{78}$ reduced the response, supporting the participation of both $\mathrm{CRF}$ receptors in the modulation of colonic permeability.

More recently, studies in several cultured epithelial cell lines, including intestinal human HT-29 cells, showed that CRF induced the upregulation of the endotoxin receptor, toll-like receptor 4 (TLR4), and that pretreatment with the $\mathrm{CRF}_{2}$ receptor antagonist, antalarmin, abrogated the response. The concomitant presence of CRF and lipopolysaccharide increased permeability to horseradish peroxidase and decreased transepithelial resistance. This effect was abolished by the $\mathrm{CRF}_{2}$ receptor antagonist, astressin $2-\mathrm{B}$, and was mediated through the upregulation of claudin-2. Similarly, the expression of TLR4 and claudin-2 increased in the small and large intestine of pregnant mice submitted to 10 days of WAS, as was enhanced the permeability to horseradish peroxidase, and the effect abolished by $\alpha$-helical $\mathrm{CRF}_{9-41}{ }^{81}$ and anti-claudin antibodies. Interestingly, rats submitted to WAS for 10 days, showed higher sensitization to orally-delivered horseradish peroxidase, as shown by enhanced intestinal permeability upon antigen re-exposure. This effect was prevented by CRF 
blockade with by $\alpha$-helical $\mathrm{CRF}_{9-41 .}{ }^{82}$

Another line of evidence in animal models highlights the relevance of stress-CRF-mast cell axis in the regulation of intestinal permeability. Elevation of intestinal permeability, in response to restraint stress or intraperitoneal administration of $\mathrm{CRF}$, was reduced or abolished after pretreatment with doxantrazole. ${ }^{59}$ Similarly, pharmacological inhibition of mast cell activation has been shown to inhibit stress-induced increased intestinal permeability in different animal models..$^{37,58,59,83}$ Stress/CRF-induced changes in the rat intestinal permeability were also significantly reduced in tissues from mast-cell deficient rats. ${ }^{45,51,59,84}$ Teitelbaum et $\mathrm{al}^{57}$ also found CRF to cause mast cell hyperplasia and abnormal bacterial attachment and/or penetration into the rat mucosa except in mast-cell deficient rats. The authors revealed that stimulation of $\mathrm{CRF}_{1}$ receptor induced an elevated secretory state, while $\mathrm{CRF}_{2}$ receptor stimulation was associated with permeability dysfunction. ${ }^{57}$ Although it is clear that mast cell activation disrupts intestinal barrier and increases intestinal permeability, the ultimate mechanisms remain to be elucidated. In this sense, several mast cell mediators have been involved. Tumor necrosis factor- $\alpha(\mathrm{TNF}-\alpha)$ has been shown to increase intestinal permeability through nuclear factor-kappa $\mathrm{B}$ activation in association with nuclear factor-kappa B-dependent downregulation of zona occludens protein-1 expression and alteration in junctional localization in Caco-2 cells, ${ }^{85}$ and through myosin light chain kinase phosphorylation. ${ }^{86}$ More recently, using a porcine ex vivo intestinal model, Overman et $\mathrm{al}^{87}$ found that CRF increased intestinal paracellular permeability via mast cell dependent release of TNF- $\alpha$ and proteases. On the other hand, the tryptase released by mast cells upon activation has been shown to induce TJs disassembly through the activation of proteinase-activated receptor-2 of the epithelial cells. ${ }^{88-90}$ These receptors can modulate enteric neurotransmission, secretion, motility, epithelial permeability, and visceral sensitivity, and are also known to regulate intestinal inflammation. ${ }^{91}$ Anatomical contacts between mast cells and enteric nerve fibers have been demonstrated in the human gastrointestinal mucosa and inflammation multiplies these contacts. ${ }^{92,93}$ Mast cells communicate, bidirectionally, with both the enteric, autonomic and central nervous system through mast cell mediators and neuropeptides. ${ }^{94}$ In fact, human mast cells synthesize and secrete both $\mathrm{CRF}$ and $\mathrm{Ucn}$ in response to immunoglobulin E receptor activation. ${ }^{95}$ Mast cells also express CRF receptors, whose activation leads to the release of cytokines and other pro-inflammatory mediators. CRF enhances the transcellular uptake of macromolecules in the human colonic mucosa in vitro, via $\mathrm{CRF}$ receptor subtypes $\mathrm{CRF}_{1}$ and $\mathrm{CRF}_{2}$ expressed on subepithelial mast cells. ${ }^{58} \mathrm{CRF}_{1}$ and $\mathrm{CRF}_{2}$ receptors have been described in human umbilical cord blood-derived mast cells, while only $\mathrm{CRF}_{1}$ receptor has been found in the human leukemic mast cell HMC-1 line. CRF stimulation induces the secretion of vascular endothelial growth factor without tryptase, histamine, IL-6, IL-8, or TNF- $\alpha$ release through $\mathrm{CRF}_{1}$ receptor. ${ }^{96}$ More recently, acute stress- induced bladder vascular permeability and vascular endothelial growth factor release have been shown to be dependent on $\mathrm{CRF}_{2}$ receptor. ${ }^{97}$

It is important to note here the ability of eosinophils to alter intestinal permeability and the mechanisms and mediators involved. ${ }^{98}$ Barrier function has been shown to be affected by eosinophil-derived major basic protein (MBP) through downregulation of occludin in a mast cell independent fashion. ${ }^{98}$ The neuropeptide substance $\mathrm{P}(\mathrm{SP})$ has been found to induce the release of vasoactive mediators from mast cells, macrophages, and $\mathrm{T}$ cells, contributing to chloride secretion, enhanced intestinal permeability, and vascular leakiness. ${ }^{99,100} \mathrm{SP}$ increases the expression of $\mathrm{CRF}_{1}$ receptor in mast cells, and in turn, $\mathrm{CRF}$ induces the expression of the specific receptor neurokinin (NK)-1. ${ }^{101}$ More recently, psychological stress, through SP release, mediated stress-induced CRF expression in mice eosinophils and eosinophil-derived CRF was responsible for mast cell activation and epithelial barrier dysfunction. In this work, a cell line of eosinophils was treated with a number of stress mediators, but only SP induced CRF release via NK-1 and NK-2. Moreover, priming of eosinophils with SP resulted in mast cell activation through eosinophil-derived CRF that in turn induced intestinal barrier dysfunction. ${ }^{102}$ Wallon et $\mathrm{al}^{83}$ examined non-inflamed colonic mucosal biopses from patients with ulcerative colitis and found that eosinophils displayed immunoreactivity to CRF. In addition, in co-culture studies, carbachol activation of eosinophils induced CRF release and subsequent activation of mast cells, which increased permeability of epithelial cells to macromolecules. ${ }^{83}$ Similar to mast cells, eosinophils have also been shown to localize close to airway nerve terminals in patients with asthma as well as in animal models of bronchial hyperreactivity. ${ }^{103,104}$ This proximity to nerve terminals is described in certain digestive disorders, ${ }^{105,106}$ providing the anatomical substrate to understand the relevance of the mast cell-eosinophil-stress/CRF axis in the regulation of epithelial permeability and the initiation of immune and inflammatory diseases.

Stress-induced increase in gut paracellular permeability has also been shown to depend on $\mathrm{CRF}_{1}$ receptor-mediated mast cell 
release of nerve growth factor (NGF). Maternal deprivation has been shown to enhance colon permeability in association with elevated NGF expression. ${ }^{76} \mathrm{~A}$ subsequent study from the same group showed that $\mathrm{CRF}$, acting through its receptor $\mathrm{CRF}_{1}$ receptor, stimulated NGF release from mast cells, which in turn increased gut paracellular permeability. ${ }^{80}$ Dendritic cells are relevant for the regulation of intestinal immune function and permeability through CRF production, a process augmented by commensal bacteria. ${ }^{107}$ Similarly, $\mathrm{CRF}_{1}$ and $\mathrm{CRF}_{2}$ receptor agonists exert a biphasic effect on macrophages. During the early stages of the inflammatory response, they suppress TNF- $\alpha$ release via induction of cyclooxygenase-2/prostaglandin E2 while later on they induce TNF- $\alpha$ transcription. ${ }^{108}$ Unfortunately, the role of CRF-mediated activation of macrophages and dendritic cells in stress-related intestinal barrier dysfunction is largely ignored.

Vanuytsel et al ${ }^{38}$ have recently shown that, both psychological stress (public speech) and a single intravenous bolus of CRF (100 $\mu \mathrm{g})$ increased small intestinal permeability in healthy humans, measured by the lactulose/mannitol ratio. Two weeks pretreatment with $800 \mathrm{mg} /$ day of the mast cell stabilizer, disodium cromoglycate, blocked the effect of both stress and CRF, invoking the participation of the CRF-mast cell axis in this response. ${ }^{38}$ We have also observed in healthy volunteers that cold pain stress enhanced both the blood-to-lumen albumin ${ }^{65}$ ratio and the blood-to-lumen mannitol and xylose permeability. ${ }^{109}$ This response was mainly observed in females with higher background stress levels, suggesting an impaired epithelial response to incoming stressful stimuli in this group. In addition, acute cold stress was shown to induce a significant release of $\alpha$-defensin in the jejunum in this study, supporting the possibility that stress might affect this protective pathway in the gut, as have been shown in the skin. ${ }^{110}$ Furthermore, we have also found that cold stress evoked a differential gender-determined increase in human intestinal macromolecular permeability. ${ }^{111}$ This enhanced permeability could lead to excessive uptake of luminal antigens and bacterial products that may initiate an inflammatory response in the mucosa. ${ }^{112}$ Other studies showing the effect of stress and CRF on intestinal and extraintestinal permeability are shown in Tables 1 and 2 , respectively.

\section{Clinical Consequences of Stress/ \\ Corticotropin-releasing Factor-mediated Dysregulation of Gastrointestinal Permeability}

The growing acknowledgment of the scientific community to the role of intestinal permeability in keeping health and well-being and its relation to the origin of digestive and extradigestive disorders is becoming more and more universal for clinicians. Increased permeability and breakdown of intestinal barrier have been implicated in the origin of gastrointestinal and liver disorders, including celiac disease, ${ }^{113}$ inflammatory bowel disease, ${ }^{114-118}$ food allergy, ${ }^{119}$ acute pancreatitis, ${ }^{120}$ irritable bowel syndrome (IBS), ${ }^{121,122}$ functional dyspepsia, ${ }^{123}$ infectious diarrheal syndromes, ${ }^{124}$ primary biliary cirrhosis, and primary sclerosing cholangitis, ${ }^{125}$ liver cirrhosis, ${ }^{126}$ alcoholic liver disease, ${ }^{127}$ liver encephalopathy, ${ }^{128}$ and gastroesophageal reflux disease, ${ }^{129-131}$ among others. However, whether enhanced gut permeability is an early manifestation of disease, a central step in disease pathogenesis, or a simple epiphenomenon, and its relationship with life stress in the clinical setting, remains to be elucidated. A few examples can illustrate this controversy.

Interestingly, life events may favor the clinical appearance of celiac disease, ${ }^{132}$ and cellular stress, through MHC class I chain related genes $\mathrm{A}$ and $\mathrm{B}$ and endoplasmic reticulum stress pathways, is linked to the disregulation of mucosal homeostasis. ${ }^{133,134}$ Early in the 80 s, celiac patients were shown to display increased intestinal permeability that normalized after several months on a gluten-free diet. ${ }^{113}$ More precise in vitro investigations revealed that although strict gluten withdrawal restored intestinal histology, a subjacent defect in mucosal permeability, measured by cellobiose/mannitol ratio, was transiently induced by short exposure to gluten, suggesting that increased intestinal permeability in celiac disease could be a primary defect. ${ }^{135}$ Recently, this defect in intestinal permeability has been related to altered expression of $\mathrm{TJ}$ genes related to permeability, polarity, and cell proliferation in active celiac disease, ${ }^{136}$ partly through the activation of the zonulin pathway in a MyD88-dependent fashion. ${ }^{137,138}$ Again, the majority of genes returned to normal after 2 years of gluten eviction with the exception of PPP2R3A, possibly indicating a constitutive defect in these patients. ${ }^{136}$ Moreover, unlike celiac disease, gluten sensitivity is not associated with increased intestinal permeability. ${ }^{139}$

Increased intestinal permeability has also been described in patients with inflammatory bowel disease. Enhanced intestinal permeability in this population is considered an initial event because it is increased in first-degree relatives of Crohn's disease patients. ${ }^{140,141}$ Several observations link clinical relapses to the increase in intestinal permeability ${ }^{142,143}$ and to life stress, ${ }^{144,145}$ partly through mast cell activation ${ }^{146}$ and the release of CRF from eosinophils $^{83}$ and neighboring nerves. ${ }^{68}$ Moreover, inflammatory 
Table 1. Studies Showing the Effect of Stress/Corticotropin-releasing Factor on Intestinal Permeability

\begin{tabular}{cc}
\hline \multicolumn{1}{c}{ Author } & Permeability assessment meth \\
$\begin{array}{c}\text { Santos et al, } \\
1999\end{array}$ & $\begin{array}{l}\text { Ussing chambers measuring } \\
\text { conductance }(G) \text {, short-current } \\
\text { circuit }(I s c) \text { and horseradish } \\
\text { peroxidase (HRP) flux in rat c }\end{array}$ \\
$\begin{array}{c}\text { Saunders } \\
\text { et al, }{ }^{33} 2002\end{array}$ & $\begin{array}{l}\text { Ussing chambers measuring G, } \\
\text { and HRP flux in rat colon }\end{array}$
\end{tabular}
Guilarte et al, ${ }^{164}$ Albumin release to the intestinal $2004 \quad$ lumen in healthy volunteers and irritable bowel syndrome

Gareau et al, ${ }^{180}$ Ussing chambers measuring $\mathrm{G}$, and $2006 \quad$ Isc in rat colon

$\begin{array}{ll}\begin{array}{l}\text { Yang et al, } \\ 2006\end{array} & \begin{array}{l}\text { Ussing chambers measuring G, Isc } \\ \text { and HRP flux in rat jejunum }\end{array} \\ \begin{array}{ll}\text { Gareau et al, } & \\ 2007 & \begin{array}{l}\text { Ussing chambers measuring HRP } \\ \text { flux in rat colon }\end{array}\end{array}\end{array}$

Santos et al, ${ }^{59} \quad$ Ussing chambers measuring $I s c$ and 2008 HRP flux in rat colon

Teitelbaum et $\mathrm{al}^{57} 2008$

Ussing chambers measuring $\mathrm{G}, I s c$ and HRP flux in rat colon

\begin{tabular}{|c|c|}
\hline $\begin{array}{l}\text { Alonso et al, } \\
2008\end{array}$ & $\begin{array}{l}\text { Albumin release to the intestinal } \\
\text { lumen in healthy volunteers }\end{array}$ \\
\hline $\begin{array}{l}\text { Wallon et al, } \\
2008\end{array}$ & $\begin{array}{l}\text { Ussing chambers measuring } I s c \text {, } \\
\text { HRP flux, }{ }^{51} \mathrm{Cr} \text {-EDTA, and } \\
\text { transepithelial resistance (TER) in } \\
\text { human colon }\end{array}$ \\
\hline $\begin{array}{l}\text { Larauche et } \\
\mathrm{al}^{48} 2009\end{array}$ & Evans blue extravasation in rat colon \\
\hline $\begin{array}{l}\text { Zheng et al, } \\
2009\end{array}$ & $\begin{array}{l}\text { Ussing chambers measuring } I s c \text {, } \\
\text { HRP flux, and TER in mouse } \\
\text { jejunum }\end{array}$ \\
\hline
\end{tabular}

Cold-restraint and water avoidance stress (WAS), and $\mathrm{CRF}$

administration

$\mathrm{CRF}$ administration $\mathrm{CRF}$ induced a significant increase in albumin release to the

Neonatal maternal separation.

WAS and oral HRP sensitization

Neonatal maternal separation

$\mathrm{CRF}$ and sauvagine exposure

CRF administration

Cold Pain Stress

$\mathrm{CRF}$ administration

Cortagine
administration
Restraint stress and
substance $\mathrm{P}(\mathrm{SP})$
exposure
intestinal lumen.

Results

Restraint stress increased colonic ion secretion and permeability to ions, bacterial peptide peptide $\mathrm{N}$-formyl-methionyl-leucylphenylalanine (fMLP), and HRP. These changes were prevented by alpha-helical $\mathrm{CRF}_{9-41}$ and mimicked by CRF administration. Pre-treatment with hexamethonium, bretylium and doxantrazole also prevented CRF-induced changes in ion secretion and $\mathrm{G}$.

Cold-restraint stress, and WAS significantly elevated G and HRP flux. CRF mimicked the stress responses. Alpha-helical $\mathrm{CRF}_{9-41}$ inhibited the stress-induced abnormalities.

Neonatal maternal separation stress increased plasmatic corticosterone, enhanced ion secretion, macromolecular permeability, bacteria adhering, and penetration into the colonic epithelium. Alpha-helical $\mathrm{CRF}_{9-41}$ reversed stress-induced effects.

Antigen challenge induced a rapid ion secretory response and an increase in G only in rats submitted to WAS. These effects were reversed by alpha-helical $\mathrm{CRF}_{9-41}$.

Neonatal maternal separation stress increased HRP flux. The enhanced flux was inhibited by atropine and hexamethonium. Alpha-helical $\mathrm{CRF}_{9-41}$ and antisauvagine-30 inhibited stress-induced increase in HRP flux.

Sauvagine and CRF induced a dose-dependent increase in Isc and HRP flux and an enhancement in protease II pre-treatment with astressin, and doxantrozole inhibited this response.

Mast-cell deficient mice displayed a reduced epithelial response to stress peptides.

Chronic CRF administration increased Isc, G, and HRP flux, but not in mast-cell deficient rats. CRF administration induced mast cell hyperplasia and abnormal bacterial attachment into the mucosa that was absent in mast-cell deficient rats.

Cold pain stress induced a significant increase in albumin release to the intestinal lumen.

CRF increased permeability to HRP. The increased permeability to $\mathrm{HRP}$ was abolished by alpha-helical $\mathrm{CRF}_{9-41}$, and lodoxamide pre-treatment.

Cortagine induced a significantly increased intestinal permeability. Astressin-B abolished the cortagine-induced increase in intestinal permeability.

SP stimulation induced a significant increase in Isc and HRP

flux in stressed mice. Those changes were lower in mast cell-deficient mice. Alpha-helical $\mathrm{CRF}_{9-41}$, inhibited SP-induced intestinal barrier dysfunction. 
Table 1. Continued

\begin{tabular}{|c|c|c|c|}
\hline Author & Permeability assessment methods & Stress model & Results \\
\hline $\begin{array}{l}\text { Smith et al, } \\
2010\end{array}$ & $\begin{array}{l}\text { Ussing chambers measuring } I s c,{ }^{3} \mathrm{H} \\
\text { mannitol flux, }{ }^{14} \mathrm{C} \text { inulin flux, and } \\
\text { TER in pig jejunum and colon }\end{array}$ & Early weaning & $\begin{array}{l}\text { Early weaning reduced jejunal TER and enhanced } I s c \text { and } \\
\text { mucosal-to-serosal flux of }{ }^{3} \mathrm{H} \text { mannitol and }{ }^{14} \mathrm{C} \text { inulin in } \\
\text { association with increased lamina propria mast cell density. } \\
\text { Sodium cromoglycolate ameliorated barrier dysfunction and } \\
\text { hypersecretion in early-weaned pigs. C } 48 / 80 \text { and } \mathrm{CRF} \text { exposure } \\
\text { increased } I s c \text { and induced intestinal barrier dysfunction that } \\
\text { were inhibited with mast cell protease inhibitors. }\end{array}$ \\
\hline $\begin{array}{l}\text { Keita et al, }{ }^{181} \\
2010\end{array}$ & $\begin{array}{l}\text { Ussing chambers measuring G, Isc, } \\
\text { HRP flux, }{ }^{51} \mathrm{Cr}-\mathrm{EDTA} \text {, and } \\
\text { Escherichia coli } \mathrm{K}-12 \text { flux in rat } \\
\text { follicle-associated epithelium (FAE) } \\
\text { and villus epithelium (VE) from rat }\end{array}$ & WAS & $\begin{array}{l}\text { WAS increased G, Isc, HRP and E. Coli uptake in FAE and VE. } \\
\text { SP increased bacterial and }{ }^{51} \mathrm{Cr} \text {-EDTA intestinal permeability. } \\
\text { These results were mimicked by CRF and carbachol and } \\
\text { reduced by doxantrazole, CRF receptor antagonist and } \\
\text { atropine. }\end{array}$ \\
\hline
\end{tabular}

$\begin{array}{lll}\text { Wallon et al, }^{83} & \text { Ussing chambers measuring } I s c, \quad \text { None } \\ & \text { HRP flux, }{ }^{51} \text { Cr-EDTA, fluorescein } \\ & \text { isothiocyanate (FITC)-Dextran } \\ & 4000, \text { and TER in non inflamed } \\ & \text { human colon biopsies from ulcerative } \\ & \text { colitis patients }\end{array}$

\begin{tabular}{|c|c|}
\hline $\begin{array}{l}\text { Alonso et al, } \\
2012\end{array}$ & $\begin{array}{l}\text { Albumin release to the intestinal } \\
\text { lumen in healthy volunteers }\end{array}$ \\
\hline $\begin{array}{l}\text { Ait-Belgnaoui } \\
\text { et al, }{ }^{182} 2012\end{array}$ & $\begin{array}{l}\text { Ussing chambers measuring } \\
\text { FITC-Dextran flux in rat colon }\end{array}$ \\
\hline
\end{tabular}

$\begin{array}{cc}\text { Overman et } & \text { Ussing chambers measuring } \\ \mathrm{al},{ }^{87} 2012 & \text { FITC-Dextran flux in porcine ileum }\end{array}$

Vicario et al, ${ }^{53} \quad$ Ussing chambers measuring $G$ and $I s c$ 2012 in rat colon

Hill LT et al, ${ }^{183}$ Lactulose-mannitol urinary excretion 2013 test in shocked patients undergoing small bowel resection during emergency laparotomy and patients undergoing elective hepatobiliary surgery

Yu et al, ${ }^{81} 2013$ HRP flux and TER in HT-29, T84, MDCK, and Caco2 monolayers Ussing chambers measuring $\mathrm{G}, I s c$, and HRP flux in mouse colon

Vanuytsel
et al, ${ }^{38} 2014 \quad \begin{aligned} & \text { Lactulose-mannitol urinary excretion } \\ & \text { test in healthy volunteers }\end{aligned}$

\section{Cold Pain Stress}

Partial restraint stress

CRF exposure Crowding stress and
CRF administration

Shock and abdominal surgery

CRF exposure and WAS

\author{
Indomethacin \\ administration, \\ public speech, $\mathrm{CRF}$ \\ administration, and \\ electroshock \\ anticipation
}

HRP flux, TER, and Isc were increased in mucosa from patients with UC. Alpha-helical $\mathrm{CRF}_{9-41}$, atropine and lodoxamide reversed the increase in intestinal permeability.

Cold pain stress induced a significant increase in albumin release to the intestinal lumen.

Stress increased plasma ACTH and corticosterone, and hypothalamic CRF and enhanced colonic paracellular permeability. Probiotic treatment prevented stress-induced increased intestinal permeability.

CRF increased paracellular FITC-Dextran flux. Pre-treatment with astressin-B, sodium cromolyn, anti-TNF- $\alpha$ antibodies, protease inhibitors, and tetrodotoxin inhibited CRF-mediated intestinal barrier dysfunction.

Crowding stress significantly increased $\mathrm{G}$ and $I_{s c}$ and CRFR 1 in the rat colon. $\mathrm{CRF}$ administration mimicked stress-induced epithelial dysfunction.

Shock was associated with increased intestinal permeability.

Plasma CRF was significantly increased in the shocked patients.

WAS increased G and Isc and HRP flux, and this increase was higher after LPS stimulation. This response was abolished by pre-treatment with anti-claudin 2 (Cldn2) antibodies. Stress also increased the expression of Cldn2 and toll-like receptor-4 (TLR4) in mouse epithelium. Exposure to CRF induced Cldn2 and TLR4 expression in intestinal epithelial cells.

Public speech and CRF administration increased intestinal permeability and salivary cortisol. Increased permeability after public speech was only present in subjects with a significant elevation of cortisol. Pre-treatment with disodium cromoglycate inhibited stress and CRF-induced increased intestinal permeability. 
Table 2. Studies Showing the Effect of Stress/Corticotropin-releasing Factor on Extraintestinal Permeability

\begin{tabular}{|c|c|c|c|}
\hline Author & Permeability assessment methods & Stress model & Results \\
\hline $\begin{array}{l}\text { Wei et al, } \\
1986\end{array}$ & Evans blue extravasation in rat paw & $\begin{array}{l}\text { Antidromic stimulation of } \\
\text { the saphenous nerve in } \\
\text { innervated rat paw }\end{array}$ & $\begin{array}{l}\text { Corticotropin-releasing factor }(\mathrm{CRF}) \text { inhibited neurogenic } \\
\text { plasma extravasation in the innervated rat paw. This effect } \\
\text { was independent of the hypothalamus or the adrenal gland. }\end{array}$ \\
\hline $\begin{array}{l}\text { Wei and } \\
\text { Kiang, }{ }^{185} 1987\end{array}$ & $\begin{array}{l}\text { Evans-blue extravasation in rat } \\
\text { trachea }\end{array}$ & $\begin{array}{l}\text { Antidromic stimulation of } \\
\text { the right vagus or exposure } \\
\text { to dilute formalin vapors }\end{array}$ & CRF inhibited tracheal plasma protein extravasation. \\
\hline $\begin{array}{l}\text { Kiang et al, } \\
1987\end{array}$ & Evans-blue extravasation in rat paw & $\begin{array}{l}\text { Immersion of rat's paw in } \\
48^{\circ} \mathrm{C} \text { or } 58^{\circ} \mathrm{C} \text { water }\end{array}$ & $\begin{array}{l}\text { CRF inhibited thermal injury-induced pasma extravasation } \\
\text { and edema. }\end{array}$ \\
\hline $\begin{array}{l}\text { Wei et al, }{ }^{187} \\
1988\end{array}$ & $\begin{array}{l}\text { Fluid displacement method in rat } \\
\text { paw }\end{array}$ & $\begin{array}{l}\text { Immersion of anesthetized } \\
\text { rat paw in } 58^{\circ} \mathrm{C} \text { water }\end{array}$ & $\begin{array}{l}\text { CRF inhibited the progressive development of swelling, and } \\
\text { reduced edema, epidermal necrosis and the disruption of } \\
\text { tissue architecture produced by thermal injury. CRF effects } \\
\text { were reverted by alpha-helical } \mathrm{CRF}_{9-41} \text {. }\end{array}$ \\
\hline $\begin{array}{l}\text { Tian and } \\
\text { Wei, }^{188} 1989\end{array}$ & $\begin{array}{l}\text { Changes in skin weight and Evans } \\
\text { blue extravasation in rat paw }\end{array}$ & $\begin{array}{l}\text { Anesthetized rat paw } \\
\text { immersion in } 12 \mathrm{~N} \\
\text { hydrochloric, } 18 \mathrm{~N} \text { sulfuric, } \\
\text { or } 14 \mathrm{~N} \text { hydrofluoric acids }\end{array}$ & CRF reduced the skin acid-induced skin injury. \\
\hline $\begin{array}{l}\text { Wei and } \\
\text { Kiang, }{ }^{189} 1989\end{array}$ & Evans blue extravasation in rat paw & $\begin{array}{l}\text { Anesthetized rat paw } \\
\text { immersion in } 48^{\circ} \mathrm{C} \text { or } 58^{\circ} \mathrm{C} \\
\text { and antidromic stimulation } \\
\text { of the saphenous nerve }\end{array}$ & $\begin{array}{l}\text { Sauvagine and CRF inhibited plasma extravasation induced } \\
\text { by thermal and neurogenic injury. }\end{array}$ \\
\hline $\begin{array}{l}\text { Serda and } \\
\text { Wei, }{ }^{190} 1991\end{array}$ & $\begin{array}{l}\text { Evans blue and Monastral } \\
\text { extravasation in rat paw }\end{array}$ & $\begin{array}{l}\text { Anesthetized rat paw } \\
\text { immersion in } 22 \% \mathrm{NaCl} \\
\text { solution maintained at } \\
-20 \pm 0.5^{\circ} \mathrm{C} \text {. }\end{array}$ & $\begin{array}{l}\mathrm{CRF} \text { inhibited the acute inflammatory response of rat paw } \\
\text { skin to cold injury. The anti-inflammatory effects of CRF } \\
\text { were blocked by alpha-helical } \mathrm{CRF}_{9-41} \text {. }\end{array}$ \\
\hline $\begin{array}{l}\text { Wei and } \\
\text { Gao, }^{191} 1991\end{array}$ & $\begin{array}{l}\text { Monastral blue extravasation in rat } \\
\text { paw }\end{array}$ & $\begin{array}{l}\text { Mechanical injury to muscle } \\
\text { produced by a midline } \\
\text { surgical incision in the } \\
\text { rectus abdominis or freeze } \\
\text { injury to the cortex } \\
\text { produced by applying a cold } \\
\text { probe }\left(-50^{\circ} \mathrm{C}\right) \text { to the skull }\end{array}$ & $\begin{array}{l}\mathrm{CRF} \text { inhibited the leakage of small blood vessel due to } \\
\text { muscle and brain injury. }\end{array}$ \\
\hline $\begin{array}{l}\text { Gao et al, }{ }^{192} \\
1991\end{array}$ & $\begin{array}{l}\text { Monastral blue extravasation in rat } \\
\text { skin, muscle, trachea and } \\
\text { esophagus }\end{array}$ & $\begin{array}{l}\text { Substance } \mathrm{P}(\mathrm{SP}) \\
\text { administration }\end{array}$ & $\begin{array}{l}\text { SP induces plasma protein leakage in skin, muscle, trachea } \\
\text { and esophagus. This effect was reverted by the treatment } \\
\text { with CRF. }\end{array}$ \\
\hline $\begin{array}{l}\text { Kelley et al, } \\
1994\end{array}$ & $\begin{array}{l}\text { Measurement of lung wet-to-dry } \\
\text { ratios to asses mice pulmonary } \\
\text { vascular leak }\end{array}$ & $\begin{array}{l}\text { Lipopolysaccharide (LPS) } \\
\text { administration }\end{array}$ & $\begin{array}{l}\text { Pulmonary vascular leak, and leukocyte infiltration were } \\
\text { significantly depressed by CRF treatment. }\end{array}$ \\
\hline $\begin{array}{l}\text { Yoshihara } \\
\text { et al, }{ }^{194} 1995\end{array}$ & $\begin{array}{l}\text { Evans blue extravasation in Guinea } \\
\text { pig trachea and main bronchi }\end{array}$ & $\begin{array}{l}\text { Antigen challenge through } \\
\text { inhalation of } 5 \% \text { ovalbumin } \\
\text { in the presence of } \\
\text { phosphoramidon }\end{array}$ & $\begin{array}{l}\mathrm{CRF} \text { reduced ovalbumin-induced plasma extravasation in } \\
\text { guinea pig airways by inhibiting the release of tachykinins } \\
\text { from primary sensory nerves. }\end{array}$ \\
\hline $\begin{array}{l}\text { Whitney } \\
\text { et al, }^{195} 1997\end{array}$ & $\begin{array}{l}\text { Comparison of rat preischemic } \\
\text { amputated limb weight with weight } \\
\text { after ischemia and reperfusion }\end{array}$ & Hind limb replantation & $\begin{array}{l}\mathrm{CRF} \text { inhibited the gain of weight by ischemia-reperfusion } \\
\text { and alpha-helical } \mathrm{CRF}_{9-41} \text { administration partially reversed } \\
\text { this effect. }\end{array}$ \\
\hline $\begin{array}{l}\text { Theoharide } \\
\text { et al, }^{196} 1998\end{array}$ & $\begin{array}{l}\text { Evans blue vascular extravasation } \\
\text { in the rat skin }\end{array}$ & $\mathrm{CRF}$ administration & $\begin{array}{l}\text { CRF induced mast cell degranulation and increased capillary } \\
\text { permeability, and the antalarmin blocked this effect. }\end{array}$ \\
\hline $\begin{array}{l}\text { Whitney } \\
\text { et al, }{ }^{197} 1998\end{array}$ & $\begin{array}{l}\text { Comparision of rat pedicled hind } \\
\text { limb weight with ischemic } \\
\text { pedicled hind limb weight }\end{array}$ & Pedicled hind limb & $\mathrm{CRF}$ administration decreased limb weight gain. \\
\hline
\end{tabular}


Table 2. Continued

\begin{tabular}{|c|c|c|c|}
\hline Author & Permeability assessment methods & Stress model & Results \\
\hline $\begin{array}{l}\text { Singh et al, } \\
1999\end{array}$ & $\begin{array}{l}\text { Evans blue vascular extravasation } \\
\text { in rat skin }\end{array}$ & $\begin{array}{l}\text { Urocortin }(\mathrm{Ucn}) \\
\text { administration }\end{array}$ & $\begin{array}{l}\text { Ucn induced rat skin mast cell degranulation and increased } \\
\text { vascular permeability. Alpha-helical } \mathrm{CRF}_{9-41} \text {, antalarmin } \\
\text { and astressin reverted this effect. }\end{array}$ \\
\hline $\begin{array}{l}\text { Rapallino } \\
\text { et al, }{ }^{199} 2001\end{array}$ & $\begin{array}{l}\text { Ionic permeability of rabbit } \\
\text { vestibular Deiters neurons } \\
\text { membrane }\end{array}$ & Rotation platform & $\begin{array}{l}\text { CRF blocked basal chloride permeation across the Deiters' } \\
\text { membranes and this effect was partially reversed by } \\
\text { alpha-helical } \mathrm{CRF}_{9-41} \text {. }\end{array}$ \\
\hline $\begin{array}{l}\text { Esposito } \\
\text { et al, }{ }^{200} 2002\end{array}$ & $\begin{array}{l}{ }^{99} \mathrm{Tc} \text { gluceptate extravasation in rat } \\
\text { brain }\end{array}$ & Restraint stress & $\begin{array}{l}\text { Acute stress and CRF paraventricular nucleus injection } \\
\text { increased blood-brain-barrier }{ }^{99} \mathrm{Tc} \text { gluceptate } \\
\text { extravasation. Antalarmin and cromolyn inhibited this } \\
\text { effect. }\end{array}$ \\
\hline $\begin{array}{l}\text { Hendryk } \\
\text { et al, }{ }^{201} 2002\end{array}$ & $\begin{array}{l}\text { Evans blue vascular extravasation } \\
\text { in rat brain }\end{array}$ & $\begin{array}{l}\text { Closing of both internal } \\
\text { carotid arteries }\end{array}$ & $\begin{array}{l}\text { CRF decreased the endothelial damage in the acute phase of } \\
\text { the ischemia. }\end{array}$ \\
\hline $\begin{array}{l}\text { Huang et } \mathrm{al}^{202} \\
2002\end{array}$ & $\begin{array}{l}{ }^{99} \mathrm{Tc} \text { gluceptate extravasation in } \\
\text { mice skin and knee joints }\end{array}$ & Restraint stress & $\begin{array}{l}\text { Vascular permeability to }{ }^{99} \mathrm{Tc} \text {, as well as local CRF levels, } \\
\text { were increased by stress, but not in mast-cell deficient mice. }\end{array}$ \\
\hline $\begin{array}{l}\text { Lytinas et al, } \\
2003\end{array}$ & $\begin{array}{l}{ }^{99} \text { Tc gluceptate and Evans blue } \\
\text { extravasation in rat skin }\end{array}$ & Restraint stress & $\begin{array}{l}\text { Acute stress increased skin CRF and vascular permeability. } \\
\text { These effects were inhibited by histamine-1 receptor } \\
\text { antagonists. }\end{array}$ \\
\hline $\begin{array}{l}\text { Donelan } \\
\text { et al, }{ }^{204} 2006\end{array}$ & $\begin{array}{l}\text { Evans blue extravasation in mice } \\
\text { skin }\end{array}$ & $\mathrm{CRF}$ administration & $\begin{array}{l}\text { CRF increased vascular permeability. The neurotensin } \\
\text { blocker (SR48692) inhibited CRF effects. CRF-induced } \\
\text { increased vascular permeability was absent in mast cell } \\
\text { deficient mice. }\end{array}$ \\
\hline $\begin{array}{l}\text { Wu et al, } \\
2006\end{array}$ & $\begin{array}{l}\text { Evans blue extravasation in the rat } \\
\text { lung }\end{array}$ & Ucn aerosol inhalation & $\begin{array}{l}\text { Ucn inhalation increased lung vascular permeability. } \\
\text { Enhanced pulmonary vascular permeability induced by } \\
\text { Ucn was markedly inhibited by pretreatment with } \\
\text { cromolyn, and azelastine. }\end{array}$ \\
\hline $\begin{array}{l}\text { Cureton et al, } \\
2009\end{array}$ & $\begin{array}{l}\text { Measurement o hydraulic and } \\
\text { macromolecule permeability in rat } \\
\text { mesenteric venules }\end{array}$ & $\begin{array}{l}\text { LPS-induced systemic } \\
\text { inflammation }\end{array}$ & $\begin{array}{l}\text { LPS and } \mathrm{Ucn}_{\mathrm{c}} \text { incremented hydraulic permeability. } \mathrm{CRF}_{2} \\
\text { receptor blockade decreased the LPS-induced increase in } \\
\text { hydraulic permeability. }\end{array}$ \\
\hline $\begin{array}{l}\text { Boucher et al, } \\
2010\end{array}$ & $\begin{array}{l}\text { Evans blue extravasation in mice } \\
\text { bladder }\end{array}$ & Restraint stress & $\begin{array}{l}\text { Acute stress increased bladder vascular permeability. } \mathrm{CRF}_{2} \\
\text { receptor and astressin }{ }_{2}-\mathrm{B} \text { inhibited this effect. }\end{array}$ \\
\hline $\begin{array}{l}\text { Song et } \mathrm{al}^{207} \\
2013\end{array}$ & $\begin{array}{l}\text { Transepithelial resistance (TER) } \\
\text { and permeability to horseradish } \\
\text { peroxidase (HRP) in human } \\
\text { endothelial cell monolayers } \\
\text { (Hmvec) }\end{array}$ & $\mathrm{CRF}$ treatment & $\begin{array}{l}\text { Exposure to CRF induced TNF-alpha release by CD14 } \\
\text { effector cells, decreased TER and increased permeability to } \\
\text { HRP in co-cultured Hmvec monolayers. }\end{array}$ \\
\hline $\begin{array}{l}\text { Wan et al, } \\
2013\end{array}$ & $\begin{array}{l}\text { Crystal violet, FITC-Dextran and } \\
\text { resistance in human umbilical vein } \\
\text { endothelial cells (HUVEC) }\end{array}$ & $\begin{array}{l}\text { Lipopolysaccharide } \\
\text { treatment }\end{array}$ & $\begin{array}{l}\text { Pretreatment of HUVECs with urocortin increased } \\
\text { LPS-induced endothelial permeability by regulating the } \\
\text { cadherin-catenin complex via } \mathrm{CRF}_{2} \text { receptor. }\end{array}$ \\
\hline
\end{tabular}

bowel disease patients show associations with genes involved in the regulation of intestinal barrier and various alterations of the transmembrane and intracytoplasmic proteins. ${ }^{147,148}$ In addition, increased $\mathrm{CRF}_{1}$ receptor ${ }^{66}$ and Ucn expression, but decreased $\mathrm{CRF}_{2}$ receptor ${ }^{67}$ expression have been shown in the colonic mucosa of active ulcerative colitis patients. ${ }^{149,150}$

Accumulating evidence also indicates that IBS is linked to abnormal intestinal permeability, ${ }^{151-153} \mathrm{CRF}$ release and life stress ${ }^{154-157}$ in close association with low-grade mucosal inflam- mation and immune activation. ${ }^{158}$ Several groups have provided preliminary evidence linking clinical manifestations of IBS to structural abnormalities of the apical junctional complex in both the small ${ }^{159,160}$ and large bowel mucosa. ${ }^{81,161-163}$ Furthermore, unpublished observations from our group indicate that a single intravenous bolus of CRF $(100 \mu \mathrm{g})$ increased intestinal permeability, measured as the blood-to-lumen albumin ratio, in healthy subjects and in IBS patients through mast cell activation. ${ }^{164}$

In the same line, increased intestinal permeability and stress/ 
CRF axis have also been involved in the pathophysiology of food allergy, as these patients display an enhancement of intestinal permeability even in the absence of food allergens ${ }^{165}$ and stress facilitates sensitization to luminal antigens. ${ }^{82}$ In fact, patients following immunosuppressive treatment have been shown to develop new-onset food allergies that may be related to the increase in intestinal permeability induced by treatment. ${ }^{166}$

Many other stress-related conditions such as severe burn, ${ }^{167,168}$ hemorragic shock, ${ }^{169}$ chronic kidney disease, ${ }^{170}$ type 1 diabetes and the metabolic syndrome, ${ }^{171,172}$ neuropsychiatric disorders, ${ }^{173}$ autism, ${ }^{174}$ autoimmune thyroiditis, ${ }^{175}$ IgA nephropathy, ${ }^{176}$ patients with primary immunodeficiencies, ${ }^{177}$ and sepsis ${ }^{178}$ have been associated with increased intestinal permeability.

\section{Conclusion}

The ability of stress and peripheral CRF to affect intestinal epithelial function and, particularly, intestinal permeability, is well documented in human and several animal species. Interestingly, apart from the direct effects on the enterocytes, the stressinduced increase of intestinal permeability is mediated via recruitment and activation of mast cells, eosinophils, macrophages and other mononuclear cells, and implicates both CRFR1 and $\mathrm{CRF}_{2}$ receptors. ${ }^{28}$

There is abundant literature supporting the link between life stress and the origin and clinical course of several human disorders, ${ }^{179}$ however, the ultimate clinical relevance of stress-CRFmediated dysregulation of gastrointestinal permeability, remains at present mostly intuitive, with few exceptions. More work in this area is needed to confirm the findings. In this sense, studies with $\mathrm{CRF}$ and related peptides and the development of new antagonists for human use, will offer the opportunity to test this hypoyhesis.

\section{Acknowledgements}

We are grateful to Maite Casado for her helpful contribution to the figure design.

\section{References}

1. Bäckhed F, Ley RE, Sonnenburg JL, Peterson DA, Gordon JI. Host-bacterial mutualism in the human intestine. Science 2005; 307:1915-1920.

2. Wells JM, Rossi O, Meijerink M, van Baarlen P. Epithelial crosstalk at the microbiota-mucosal interface. Proc Natl Acad Sci USA 2011;108(suppl 1):4607-4614.

3. Hooper LV, Macpherson AJ. Immune adaptations that maintain homeostasis with the intestinal microbiota. Nat Rev Immunol 2010; 10:159-169.

4. Caricilli AM, Castoldi A, Câmara NOS. Intestinal barrier: a gentlemen's agreement between microbiota and immunity. World J Gastrointest Pathophysiol 2014;5:18-32.

5. Mazmanian SK, Round JL, Kasper DL. A microbial symbiosis factor prevents intestinal inflammatory disease. Nature 2008;453:620625.

6. Söderholm JD, Perdue MH. Stress and gastrointestinal tract. II. Stress and intestinal barrier function. Am J Physiol Gastrointest Liver Physiol 2001;280:G7-G13.

7. Cicchetti D, Cohen DJ, eds. Developmental psychopathology. 2nd ed. Hoboken: John Wiley \& Sons 2006.

8. Mawdsley JE, Rampton DS. Psychological stress in IBD: new insights into pathogenic and therapeutic implications. Gut 2005;54: 1481-1491.

9. Turner JR. Intestinal mucosal barrier function in health and disease. Nat Rev Immunol 2009;9:799-809.

10. Kato LM, Kawamoto S, Maruya M, Fagarasan S. The role of the adaptive immune system in regulation of gut microbiota. Immunol Rev 2014;260:67-75.

11. Wood JD. Neuropathophysiology of functional gastrointestinal disorders. World J Gastroenterol 2007;13:1313-1332.

12. Donelan J, Marchand JE, Kempuraj D, Papadopoulou N, Papaliodis D, Theoharides TC. Perifollicular and perivascular mouse skin mast cells express corticotropin-releasing hormone receptor. J Invest Dermatol 2006;126:929-932.

13. Larauche M, Kiank C, Tache Y. Corticotropin releasing factor signaling in colon and ileum: regulation by stress and pathophysiological implications. J Physiol Pharmacol 2009;60(suppl 7):33-46.

14. Sansonetti PJ. War and peace at mucosal surfaces. Nat Rev Immunol 2004;4:953-964.

15. Brostoff J, Challacombe SJ. Food Allergy \& Intolerance. London: Saunders (W.B.) Co Ltd (Elsevier Health Sciences) 2002.

16. Pastorelli L, De Salvo C, Mercado JR, Vecchi M, Pizarro TT. Central role of the gut epithelial barrier in the pathogenesis of chronic intestinal inflammation: lessons learned from animal models and human genetics. Front Immunol 2013;4:280.

17. Nusrat A, Turner JR, Madara JL. Molecular physiology and pathophysiology of tight junctions. IV. Regulation of tight junctions by extracellular stimuli: nutrients, cytokines, and immune cells. Am J Physiol Gastrointest Liver Physiol 2000;279:G851-G857.

18. Ménard S, Cerf-Bensussan N, Heyman M. Multiple facets of intestinal permeability and epithelial handling of dietary antigens. Mucosal Immunol 2010;3:247-259.

19. Chen HQ, Yang J, Zhang M. Lactobacillus plantarum ameliorates colonic epithelial barrier dysfunction by modulating the apical junctional complex and PepT1 in IL-10 knockout mice. Am J Physiol Gastrointest Liver Physiol 2010;299:G1287-G1297.

20. Su L, Shen L, Clayburgh DR. Targeted epithelial tight junction dysfunction causes immune activation and contributes to development of experimental colitis. Gastroenterology 2009;136:551-563.

21. Alonso C, Vicario M, Pigrau M, Lobo B, Santos J. Intestinal barrier function and the brain-gut axis. Adv Exp Med Biol 2014;817: 
73-113.

22. Konturek PC, Brzozowski T, Konturek SJ. Stress and the gut: pathophysiology, clinical consequences, diagnostic approach and treatment options. J Physiol Pharmacol 2011;62:591-599.

23. Lambert GP. Stress-induced gastrointestinal barrier dysfunction and its inflammatory effects. J Anim Sci 2009;87:E101-E108.

24. Gareau MG, Silva MA, Perdue MH. Pathophysiological mechanisms of stress-induced intestinal damage. Curr Mol Med 2008;8: 274-281.

25. Hart A, Kamm MA. Review article: mechanisms of initiation and perpetuation of gut inflammation by stress. Aliment Pharmacol Ther 2002;16:2017-2028.

26. Hauger RL, Grigoriadis DE, Dallman MF, Plotsky PM, Vale WW, Dautzenberg FM. International Union of Pharmacology. XXXVI. Current status of the nomenclature for receptors for corticotropin-releasing factor and their ligands. Pharmacol Rev 2003;5 5: 21-26.

27. Fekete EM, Zorrilla EP. Physiology, pharmacology, and therapeutic relevance of urocortins in mammals: ancient CRF paralogs. Front Neuroendocrinol 2007;28:1-27.

28. Kiank C, Taché Y, Larauche M. Stress-related modulation of inflammation in experimental models of bowel disease and post-infectious irritable bowel syndrome: role of corticotropin-releasing factor receptors. Brain Behav Immun 2010;24:41-48.

29. la Fleur SE, Wick EC, Idumalla PS, Grady EF, Bhargava A. Role of peripheral corticotropin-releasing factor and urocortin II in intestinal inflammation and motility in terminal ileum. Proc Natl Acad Sci USA 2005;102:7647-7652.

30. Kokkotou E, Torres D, Moss AC, et al. Corticotropin-releasing hormone receptor 2-deficient mice have reduced intestinal inflammatory responses. J Immunol 2006;177:3355-3361.

31. Meddings JB, Swain MG. Environmental stress-induced gastrointestinal permeability is mediated by endogenous glucocorticoids in the rat. Gastroenterology 2000;119:1019-1028.

32. Kiliaan AJ, Saunders PR, Bijlsma PB, et al. Stress stimulates transepithelial macromolecular uptake in rat jejunum. Am J Physiol 1998;275:G1037-G1044.

33. Saunders PR, Santos J, Hanssen NP, Yates D, Groot JA, Perdue MH. Physical and psychological stress in rats enhances colonic epithelial permeability via peripheral CRH. Dig Dis Sci 2002;47: 208-215.

34. Liźko NN, Silov VM, Syrych GD. [Events in he development of dysbacteriosis of the intestines in man under extreme conditions]. Nahrung 1984;28:599-605. [German]

35. Lyte M, Ernst S. Catecholamine induced growth of gram negative bacteria. Life Sci 1992;50:203-212.

36. Castagliuolo I, Lamont JT, Qiu B, et al. Acute stress causes mucin release from rat colon: role of corticotropin releasing factor and mast cells. Am J Physiol 1996;271(5 Pt 1):G884-G892.

37. Santos J, Saunders PR, Hanssen NP, et al. Corticotropin-releasing hormone mimics stress-induced colonic epithelial pathophysiology in the rat. Am J Physiol 1999;277(2 Pt 1):G391-G399.

38. Vanuytsel T, van Wanrooy S, Vanheel H, et al. Psychological stress and corticotropin-releasing hormone increase intestinal permeability in humans by a mast cell-dependent mechanism. Gut 2014;63: 1293-1299.
39. Farhadi A, Banan A, Fields J, Keshavarzian A. Intestinal barrier: an interface between health and disease. J Gastroenterol Hepatol 2003; 18:479-497.

40. Liévin-Le Moal V, Servin AL. The front line of enteric host defense against unwelcome intrusion of harmful microorganisms: mucins, antimicrobial peptides, and microbiota. Clin Microbiol Rev 2006; 19:315-337.

41. Gibson P, Rosella O, Nov R, Young G. Colonic epithelium is diffusely abnormal in ulcerative colitis and colorectal cancer. Gut 1995;36:857-863.

42. Chatzaki E, Crowe PD, Wang L, Million M, Taché Y, Grigoriadis DE. CRF receptor type 1 and 2 expression and anatomical distribution in the rat colon. J Neurochem 2004;90:309-316.

43. Castagliuolo I, Wershil BK, Karalis K, Pasha A, Nikulasson ST, Pothoulakis C. Colonic mucin release in response to immobilization stress is mast cell dependent. Am J Physiol 1998;274(6 Pt 1): G1094-G1100.

44. Pfeiffer CJ, Qiu B, Lam SK. Reduction of colonic mucus by repeated short-term stress enhances experimental colitis in rats. J Physiol Paris 2001;95:81-87.

45. Söderholm JD, Yang PC, Ceponis $\mathrm{P}$, et al. Chronic stress induces mast cell-dependent bacterial adherence and initiates mucosal inflammation in rat intestine. Gastroenterology 2002;123:1099-1108.

46. Hirata T, Keto Y, Nakata M, et al. Effects of serotonin 5-HT 3 receptor antagonists on stress-induced colonic hyperalgesia and diarrhoea in rats: a comparative study with opioid receptor agonists, a muscarinic receptor antagonist and a synthetic polymer. Neurogastroenterol Motil 2008;20:557-565.

47. Saunders PR, Maillot C, Million M, Taché Y. Peripheral corticotropin-releasing factor induces diarrhea in rats: role of CRF1 receptor in fecal watery excretion. Eur J Pharmacol 2002;435:231235.

48. Larauche M, Gourcerol G, Wang L, et al. Cortagine, a CRF1 agonist, induces stresslike alterations of colonic function and visceral hypersensitivity in rodents primarily through peripheral pathways. Am J Physiol Gastrointest Liver Physiol 2009;297:G215-G227.

49. Yuan PQ, Million M, Wu SV, Rivier J, Taché Y. Peripheral corticotropin releasing factor $(\mathrm{CRF})$ and a novel CRF1 receptor agonist, stressin1-A activate CRF1 receptor expressing cholinergic and nitrergic myenteric neurons selectively in the colon of conscious rats. Neurogastroenterol Motil 2007;19:923-936.

50. Saunders PR, Kosecka U, McKay DM, Perdue MH. Acute stressors stimulate ion secretion and increase epithelial permeability in rat intestine. Am J Physiol 1994;267(5 Pt 1):G794-G799.

51. Santos J, Benjamin M, Yang PC, Prior T, Perdue MH. Chronic stress impairs rat growth and jejunal epithelial barrier function: role of mast cells. Am J Physiol Gastrointest Liver Physiol 2000;278: G847-G854.

52. Vicario M, Guilarte M, Alonso C, et al. Chronological assessment of mast cell-mediated gut dysfunction and mucosal inflammation in a rat model of chronic psychosocial stress. Brain Behav Immun 2010;24:1166-1175.

53. Vicario M, Alonso C, Guilarte M, et al. Chronic psychosocial stress induces reversible mitochondrial damage and corticotropin-releasing factor receptor type-1 upregulation in the rat intestine and IBS-like gut dysfunction. Psychoneuroendocrinology 2012;37:65-77. 
54. Cameron HL, Perdue MH. Stress impairs murine intestinal barrier function: improvement by glucagon-like peptide-2. J Pharmacol Exp Ther 2005;314:214-220.

55. Söderholm JD, Yates DA, Gareau MG, Yang PC, MacQueen G, Perdue MH. Neonatal maternal separation predisposes adult rats to colonic barrier dysfunction in response to mild stress. Am J Physiol Gastrointest Liver Physiol 2002;283:G1257-G1263.

56. Zareie M, Johnson-Henry K, Jury J, et al. Probiotics prevent bacterial translocation and improve intestinal barrier function in rats following chronic psychological stress. Gut 2006;55:1553-1560.

57. Teitelbaum AA, Gareau MG, Jury J, Yang PC, Perdue MH. Chronic peripheral administration of corticotropin-releasing factor causes colonic barrier dysfunction similar to psychological stress. Am J Physiol Gastrointest Liver Physiol 2008;295:G452-G459.

58. Smith F, Clark JE, Overman BL, et al. Early weaning stress impairs development of mucosal barrier function in the porcine intestine. Am J Physiol Gastrointest Liver Physiol 2010;298:G352-G363.

59. Santos J, Yates D, Guilarte M, Vicario M, Alonso C, Perdue MH. Stress neuropeptides evoke epithelial responses via mast cell activation in the rat colon. Psychoneuroendocrinology 2008;33:1248-1256.

60. Liu S, Gao X, Gao N, et al. Expression of type 1 corticotropin-releasing factor receptor in the guinea pig enteric nervous system. J Comp Neurol 2005;481:284-298.

61. Liu S, Ren W, Qu MH, et al. Differential actions of urocortins on neurons of the myenteric division of the enteric nervous system in guinea pig distal colon. Br J Pharmacol 2010;159:222-236.

62. Barclay GR, Turnberg LA. Effect of psychological stress on salt and water transport in the human jejunum. Gastroenterology 1987; 93:91-97.

63. Barclay GR, Turnberg LA. Effect of cold-induced pain on salt and water transport in the human jejunum. Gastroenterology 1988;94: 994-998.

64. Santos J, Bayarri C, Saperas E, et al. Characterisation of immune mediator release during the immediate response to segmental mucosal challenge in the jejunum of patients with food allergy. Gut 1999;45:553-558.

65. Alonso C, Guilarte M, Vicario M, et al. Maladaptive intestinal epithelial responses to life stress may predispose healthy women to gut mucosal inflammation. Gastroenterology 2008;135:163-172, e1.

66. Yuan PQ, Wu SV, Elliott J, et al. Expression of corticotropin releasing factor receptor type 1 (CRF1) in the human gastrointestinal tract and upregulation in the colonic mucosa in patients with ulcerative colitis. Peptides 2012;38:62-69.

67. Chatzaki E, Anton PA, Million M, et al. Corticotropin-releasing factor receptor subtype 2 in human colonic mucosa: down-regulation in ulcerative colitis. World J Gastroenterol 2013;19:14161423.

68. Wallon C, Yang PC, Keita AV et al. Corticotropin-releasing hormone $(\mathrm{CRH})$ regulates macromolecular permeability via mast cells in normal human colonic biopsies in vitro. Gut 2008;57:50-58.

69. Bijlsma PB, van Raaij MT, Dobbe CJ, et al. Subchronic mild noise stress increases HRP permeability in rat small intestine in vitro. Physiol Behav 2001;73:43-49.

70. Demaude J, Salvador-Cartier C, Fioramonti J, Ferrier L, Bueno L. Phenotypic changes in colonocytes following acute stress or activation of mast cells in mice: implications for delayed epithelial barrier dysfunction. Gut 2006;5 5:655-661.

71. Saunders PR, Hanssen NP, Perdue MH. Cholinergic nerves mediate stress-induced intestinal transport abnormalities in Wistar-Kyoto rats. Am J Physiol 1997;273(2 Pt 1):G486-G490.

72. Kuge T, Greenwood-Van Meerveld B, Sokabe M. Stress-induced breakdown of intestinal barrier function in the rat: reversal by wood creosote. Life Sci 2006;79:913-918.

73. Ferrier L, Mazelin L, Cenac N, et al. Stress-induced disruption of colonic epithelial barrier: role of interferon-gamma and myosin light chain kinase in mice. Gastroenterology 2003;125:795-804.

74. Weber CR, Raleigh DR, Su L, et al. Epithelial myosin light chain kinase activation induces mucosal interleukin-13 expression to alter tight junction ion selectivity. J Biol Chem 2010;285:12037-12046.

75. Santos J, Perdue MH. Stress and neuroimmune regulation of gut mucosal function. Gut 2000;47(suppl 4):iv49-iv51; discussion iv52.

76. Barreau F, Cartier C, Ferrier L, Fioramonti J, Bueno L. Nerve growth factor mediates alterations of colonic sensitivity and mucosal barrier induced by neonatal stress in rats. Gastroenterology 2004; 127:524-534.

77. Barreau F, Ferrier L, Fioramonti J, Bueno L. Neonatal maternal deprivation triggers long term alterations in colonic epithelial barrier and mucosal immunity in rats. Gut 2004;53:501-506.

78. Gareau MG, Jury J, Perdue MH. Neonatal maternal separation of rat pups results in abnormal cholinergic regulation of epithelial permeability. Am J Physiol Gastrointest Liver Physiol 2007;293: G198-G203.

79. Kim YS, Lee MY, Ryu HS, et al. Regional differences in chronic stress-induced alterations in mast cell and protease-activated receptor-2-positive cell numbers in the colon of Ws/Ws Rats. J Neurogastroenterol Motil 2014;20:54-63.

80. Barreau F, Cartier C, Leveque M, et al. Pathways involved in gut mucosal barrier dysfunction induced in adult rats by maternal deprivation: corticotrophin-releasing factor and nerve growth factor interplay. J Physiol 2007;580(Pt 1):347-356.

81. Yu Y, Liu Z-Q, Liu X-Y, et al. Stress-derived corticotropin releasing factor breaches epithelial endotoxin tolerance. PloS One 2013; 8:e65760.

82. Yang PC, Jury J, Söderholm JD, Sherman PM, McKay DM, Perdue MH. Chronic psychological stress in rats induces intestinal sensitization to luminal antigens. Am J Pathol 2006;168:104-114.

83. Wallon C, Persborn M, Jönsson M, et al. Eosinophils express muscarinic receptors and corticotropin-releasing factor to disrupt the mucosal barrier in ulcerative colitis. Gastroenterology 2011;140: 1597-1607.

84. Santos J, Yang PC, Söderholm JD, Benjamin M, Perdue MH. Role of mast cells in chronic stress induced colonic epithelial barrier dysfunction in the rat. Gut 2001;48:630-636.

85. Ma TY, Iwamoto GK, Hoa NT, et al. TNF-alpha-induced increase in intestinal epithelial tight junction permeability requires NF-kappa B activation. Am J Physiol Gastrointest Liver Physiol 2004;286:G367-G376.

86. Zolotarevsky Y, Hecht G, Koutsouris A, et al. A membrane-permeant peptide that inhibits MLC kinase restores barrier function in in vitro models of intestinal disease. Gastroenterology 2002;123: 163-172.

87. Overman EL, Rivier JE, Moeser AJ. CRF induces intestinal epi- 
thelial barrier injury via the release of mast cell proteases and TNF- $\alpha$. PloS One 2012;7:e39935.

88. Jacob C, Yang PC, Darmoul D, et al. Mast cell tryptase controls paracellular permeability of the intestine. Role of protease-activated receptor 2 and beta-arrestins. J Biol Chem 2005;280:31936-31948.

89. Gebhardt T, Gerhard R, Bedoui S, et al. Beta2-adrenoceptor-mediated suppression of human intestinal mast cell functions is caused by disruption of filamentous actin dynamics. Eur J Immunol 2005;35: 1124-1132.

90. Goldblum SE, Rai U, Tripathi A, et al. The active Zot domain (aa 288-293) increases ZO-1 and myosin 1C serine/threonine phosphorylation, alters interaction between ZO-1 and its binding partners, and induces tight junction disassembly through proteinase activated receptor 2 activation. FASEB J 2011;25:144-158.

91. Vergnolle N. Clinical relevance of proteinase activated receptors (pars) in the gut. Gut 2005;54:867-874.

92. Stead RH, Dixon MF, Bramwell NH, Riddell RH, Bienenstock J. Mast cells are closely apposed to nerves in the human gastrointestinal mucosa. Gastroenterology 1989;97:575-585.

93. Barbara G, Stanghellini V, De Giorgio R, et al. Activated mast cells in proximity to colonic nerves correlate with abdominal pain in irritable bowel syndrome. Gastroenterology 2004;126:693-702.

94. Buhner S, Schemann M. Mast cell-nerve axis with a focus on the human gut. Biochim Biophys Acta 2012;1822:85-92.

95. Kempuraj D, Papadopoulou NG, Lytinas M, et al. Corticotropinreleasing hormone and its structurally related urocortin are synthesized and secreted by human mast cells. Endocrinology 2004;145: 43-48.

96. Cao J, Papadopoulou N, Kempuraj D, et al. Human mast cells express corticotropin-releasing hormone $(\mathrm{CRH})$ receptors and $\mathrm{CRH}$ leads to selective secretion of vascular endothelial growth factor. J Immunol 2005;174:7665-7675.

97. Boucher W, Kempuraj D, Michaelian M, Theoharides TC. Corticotropin-releasing hormone-receptor 2 is required for acute stress-induced bladder vascular permeability and release of vascular endothelial growth factor. BJU Int 2010;106:1394-1399.

98. Furuta GT, Nieuwenhuis EES, Karhausen J, et al. Eosinophils alter colonic epithelial barrier function: role for major basic protein. Am J Physiol Gastrointest Liver Physiol 2005;289:G890-G897.

99. Koon HW, Pothoulakis C. Immunomodulatory properties of substance P: the gastrointestinal system as a model. Ann N Y Acad Sci 2006;1088:23-40.

100. Wang L, Stanisz AM, Wershil BK, Galli SJ, Perdue MH. Substance $\mathrm{P}$ induces ion secretion in mouse small intestine through effects on enteric nerves and mast cells. Am J Physiol 1995;269(1 Pt 1):G85-G92.

101. Asadi S, Alysandratos KD, Angelidou A, et al. Substance P(SP) induces expression of functional corticotropin-releasing hormone receptor-1 (CRHR-1) in human mast cells. J Invest Dermatol 2012; 132:324-329.

102. Zheng PY, Feng BS, Oluwole C, et al. Psychological stress induces eosinophils to produce corticotrophin releasing hormone in the intestine. Gut 2009;58:1473-1479.

103. Thornton MA, Akasheh N, Walsh MT, et al. Eosinophil recruitment to nasal nerves after allergen challenge in allergic rhinitis. Clin Immunol 2013;147:50-57.
104. Kingham PJ, Costello RW, McLean WG. Eosinophil and airway nerve interactions. Pulm Pharmacol Ther 2003;16:9-13.

105. O'Brien LM, Fitzpatrick E, Baird AW, Campion DP. Eosinophilnerve interactions and neuronal plasticity in rat gut associated lymphoid tissue (GALT) in response to enteric parasitism. J Neuroimmunol 2008;197:1-9.

106. Bischoff SC, Gebhardt T. Role of mast cells and eosinophils in neuroimmune interactions regulating mucosal inflammation in inflammatory bowel disease. Adv Exp Med Biol 2006;579:177-208.

107. Hojo M, Ohkusa T, Tomeoku H, et al. Corticotropin-releasing factor secretion from dendritic cells stimulated by commensal bacteria. World J Gastroenterol 2011;17:4017-4022.

108. Tsatsanis C, Androulidaki A, Dermitzaki E, Gravanis A, Margioris AN. Corticotropin releasing factor receptor $1(\mathrm{CRF} 1)$ and $\mathrm{CRF} 2$ agonists exert an anti-inflammatory effect during the early phase of inflammation suppressing LPS-induced TNF-alpha release from macrophages via induction of COX-2 and PGE2. J Cell Physiol 2007;210:774-783.

109. Rezzi S, Martin FP, Alonso C, et al. Metabotyping of biofluids reveals stress-based differences in gut permeability in healthy individuals. J Proteome Res 2009;8:4799-4809.

110. Aberg KM, Radek KA, Choi EH, et al. Psychological stress downregulates epidermal antimicrobial peptide expression and increases severity of cutaneous infections in mice. J Clin Invest 2007;117: 3339-3349.

111. Alonso C, Guilarte M, Vicario M, et al. Acute experimental stress evokes a differential gender-determined increase in human intestinal macromolecular permeability. Neurogastroenterol Motil 2012;24: 740-746,e348-349.

112. Ando T, Rivier J, Yanaihara H, Arimura A. Peripheral corticotropin-releasing factor mediates the elevation of plasma IL-6 by immobilization stress in rats. Am J Physiol 1998;275(5 Pt 2):R1461R1467.

113. Bjarnason I, Peters TJ. In vitro determination of small intestinal permeability: demonstration of a persistent defect in patients with coeliac disease. Gut 1984;25:145-150.

114. Sartor RB. Mechanisms of disease: pathogenesis of Crohn's disease and ulcerative colitis. Nat Clin Pract Gastroenterol Hepatol 2006; 3:390-407.

115. Clavel T, Haller D. Bacteria- and host-derived mechanisms to control intestinal epithelial cell homeostasis: implications for chronic inflammation. Inflamm Bowel Dis 2007;13:1153-1164.

116. Pearson AD, Eastham EJ, Laker MF, Craft AW, Nelson R. Intestinal permeability in children with Crohn's disease and coeliac disease. Br Med J (Clin Res Ed) 1982;285:20-21.

117. Bjarnason I, O'Morain C, Levi AJ, Peters TJ. Absorption of 51chromium-labeled ethylenediaminetetraacetate in inflammatory bowel disease. Gastroenterology 1983;85:318-322.

118. Heller F, Florian P, Bojarski C, et al. Interleukin-13 is the key effector Th2 cytokine in ulcerative colitis that affects epithelial tight junctions, apoptosis, and cell restitution. Gastroenterology 2005; 129:550-564.

119. Järvinen KM, Konstantinou GN, Pilapil M, et al. Intestinal permeability in children with food allergy on specific elimination diets. Pediatr Allergy Immunol 2013;24:589-595.

120. Fishman JE, Levy G, Alli V, Zheng X, Mole DJ, Deitch EA. The 
intestinal mucus layer is a critical component of the gut barrier that is damaged during acute pancreatitis. Shock 2014;42:264-270.

121. Camilleri M, Gorman H. Intestinal permeability and irritable bowel syndrome. Neurogastroenterol Motil 2007;19:545-552.

122. Lee H, Park JH, Park DI, et al. Mucosal mast cell count is associated with intestinal permeability in patients with diarrhea predominant irritable bowel syndrome. J Neurogastroenterol Motil 2013; 19:244-250.

123. Vanheel H, Vicario M, Vanuytsel T, et al. Impaired duodenal mucosal integrity and low-grade inflammation in functional dyspepsia. Gut 2014;63:262-271.

124. Gadewar S, Fasano A. Current concepts in the evaluation, diagnosis and management of acute infectious diarrhea. Curr Opin Pharmacol 2005;5:559-565.

125. Sakisaka S, Kawaguchi T, Taniguchi E, et al. Alterations in tight junctions differ between primary biliary cirrhosis and primary sclerosing cholangitis. Hepatology 2001;33:1460-1468.

126. Pijls KE, Jonkers DM, Elamin EE, Masclee AA, Koek GH. Intestinal epithelial barrier function in liver cirrhosis: an extensive review of the literature. Liver Int 2013;33:1457-1469.

127. Rao RK, Seth A, Sheth P. Recent advances in alcoholic liver disease I. Role of intestinal permeability and endotoxemia in alcoholic liver disease. Am J Physiol Gastrointest Liver Physiol 2004;286:G881G884.

128. Summa KC, Voigt RM, Forsyth CB, et al. Disruption of the circadian clock in mice increases intestinal permeability and promotes alcohol-induced hepatic pathology and inflammation. PloS One 2013;8:e67102.

129. Li J, Brackbill RM, Stellman SD, et al. Gastroesophageal reflux symptoms and comorbid asthma and posttraumatic stress disorder following the 9/11 terrorist attacks on World Trade Center in New York City. Am J Gastroenterol 2011;106:1933-1941.

130. Farré R, Blondeau K, Clement D, et al. Evaluation of oesophageal mucosa integrity by the intraluminal impedance technique. Gut 2011;60:885-892.

131. Söderholm JD. Stress-related changes in oesophageal permeability: filling the gaps of GORD? Gut 2007;56:1177-1180.

132. Ciacci C, Siniscalchi M, Bucci C, Zingone F, Morra I, Iovino P. Life events and the onset of celiac disease from a patient's perspective. Nutrients 2013;5:3388-3398.

133. Allegretti YL, Bondar C, Guzman L, et al. Broad MICA/B expression in the small bowel mucosa: a link between cellular stress and celiac disease. PloS One 2013;8:e73658.

134. Caputo I, Secondo A, Lepretti M, et al. Gliadin peptides induce tissue transglutaminase activation and ER-stress through $\mathrm{Ca}^{2+}$ mobilization in Caco-2 cells. PloS One 2012;7:e45209.

135. Hamilton I, Cobden I, Rothwell J, Axon AT. Intestinal permeability in coeliac disease: the response to gluten withdrawal and single-dose gluten challenge. Gut 1982;23:202-210.

136. Jauregi-Miguel A, Fernandez-Jimenez N, Irastorza I, Plaza-Izurieta L, Vitoria JC, Bilbao JR. Alteration of tight junction gene expression in celiac disease. J Pediatr Gastroenterol Nutr 2014;58: 762-767.

137. Lammers KM, Lu R, Brownley J, et al. Gliadin induces an increase in intestinal permeability and zonulin release by binding to the chemokine receptor CXCR3. Gastroenterology 2008;135:194-204, e3.
138. Wang W, Uzzau S, Goldblum SE, Fasano A. Human zonulin, a potential modulator of intestinal tight junctions. J Cell Sci 2000; 113(Pt 24):4435-4440.

139. Sapone A, Lammers KM, Casolaro V, et al. Divergence of gut permeability and mucosal immune gene expression in two glutenassociated conditions: celiac disease and gluten sensitivity. BMC Med 2011;9:23.

140. Hollander D, Vadheim CM, Brettholz E, Petersen GM, Delahunty T, Rotter JI. Increased intestinal permeability in patients with Crohn's disease and their relatives. A possible etiologic factor. Ann Intern Med 1986;105:883-885

141. Kucharzik T, Walsh SV, Chen J, Parkos CA, Nusrat A. Neutrophil transmigration in inflammatory bowel disease is associated with differential expression of epithelial intercellular junction proteins. Am J Pathol 2001;159:2001-2009.

142. D'Incà R, Di Leo V, Corrao G, et al. Intestinal permeability test as a predictor of clinical course in Crohn's disease. Am J Gastroenterol 1999;94:2956-2960.

143. Arnott ID, Kingstone K, Ghosh S. Abnormal intestinal permeability predicts relapse in inactive Crohn disease. Scand J Gastroenterol 2000;35:1163-1169.

144. Singh S, Graff LA, Bernstein CN. Do NSAIDs, antibiotics, infections, or stress trigger flares in IBD? Am J Gastroenterol 2009; 104:1298-1313.

145. Cámara RJ, Ziegler R, Begré S, Schoepfer AM, von Känel R, Swiss Inflammatory Bowel Disease Cohort Study (SIBDCS) group. The role of psychological stress in inflammatory bowel disease: quality assessment of methods of 18 prospective studies and suggestions for future research. Digestion 2009;80:129-139.

146. Farhadi A, Fields JZ, Keshavarzian A. Mucosal mast cells are pivotal elements in inflammatory bowel disease that connect the dots: stress, intestinal hyperpermeability and inflammation. World J Gastroenterol 2007;13:3027-3030.

147. Merga Y, Campbell BJ, Rhodes JM. Mucosal barrier, bacteria and inflammatory bowel disease: possibilities for therapy. Dig Dis 2014; 32:475-483.

148. Fries W, Belvedere A, Vetrano S. Sealing the broken barrier in IBD: intestinal permeability, epithelial cells and junctions. Curr Drug Targets 2013;14:1460-1470.

149. Moss AC, Anton P, Savidge T, et al. Urocortin II mediates pro-inflammatory effects in human colonocytes via corticotropin-releasing hormone receptor 2alpha. Gut 2007;56:1210-1217.

150. Saruta M, Takahashi K, Suzuki T, Torii A, Kawakami M, Sasano $\mathrm{H}$. Urocortin 1 in colonic mucosa in patients with ulcerative colitis. J Clin Endocrinol Metab 2004;89:5352-5361.

151. Dunlop SP, Hebden J, Campbell E, et al. Abnormal intestinal permeability in subgroups of diarrhea-predominant irritable bowel syndromes. Am J Gastroenterol 2006;101:1288-1294.

152. Mujagic Z, Ludidi S, Keszthelyi D, et al. Small intestinal permeability is increased in diarrhoea predominant IBS, while alterations in gastroduodenal permeability in all IBS subtypes are largely attributable to confounders. Aliment Pharmacol Ther 2014;40:288-297.

153. Piche $T$, Barbara $G$, Aubert $P$, et al. Impaired intestinal barrier integrity in the colon of patients with irritable bowel syndrome: involvement of soluble mediators. Gut 2009;58:196-201.

154. Taché Y, Martinez V, Wang L, Million M. CRF1 receptor signal- 
ing pathways are involved in stress-related alterations of colonic function and viscerosensitivity: implications for irritable bowel syndrome. Br J Pharmacol 2004;141:1321-1330.

155. Fukudo S. Role of corticotropin-releasing hormone in irritable bowel syndrome and intestinal inflammation. J Gastroenterol 2007; 42(suppl 17):48-51.

156. Labus JS, Hubbard CS, Bueller J, et al. Impaired emotional learning and involvement of the corticotropin-releasing factor signaling system in patients with irritable bowel syndrome. Gastroenterology 2013;145:1253-1261, e1-e3.

157. Bennett EJ, Tennant CC, Piesse C, Badcock CA, Kellow JE. Level of chronic life stress predicts clinical outcome in irritable bowel syndrome. Gut 1998;43:256-261.

158. O'Malley D, Quigley EM, Dinan TG, Cryan JF. Do interactions between stress and immune responses lead to symptom exacerbations in irritable bowel syndrome? Brain Behav Immun 2011;25: 1333-1341.

159. Martínez C, Lobo B, Pigrau M, et al. Diarrhoea-predominant irritable bowel syndrome: an organic disorder with structural abnormalities in the jejunal epithelial barrier. Gut 2013;62:1160-1168.

160. Martínez C, Vicario M, Ramos L, et al. The jejunum of diarrhea-predominant irritable bowel syndrome shows molecular alterations in the tight junction signaling pathway that are associated with mucosal pathobiology and clinical manifestations. Am J Gastroenterol 2012;107:736-746.

161. Wilcz-Villega E, McClean S, O'Sullivan M. Reduced E-cadherin expression is associated with abdominal pain and symptom duration in a study of alternating and diarrhea predominant IBS. Neurogastroenterol Motil 2014;26:316-325.

162. Bertiaux-Vandaële N, Youmba SB, Belmonte L, et al. The expression and the cellular distribution of the tight junction proteins are altered in irritable bowel syndrome patients with differences according to the disease subtype. Am J Gastroenterol 2011;106:21652173.

163. Piche T. Tight junctions and IBS--the link between epithelial permeability, low-grade inflammation, and symptom generation? Neurogastroenterol Motil 2014;26:296-302.

164. Guilarte M, Santos J, Alonso C, et al. Corticotropin-releasing hormone $(\mathrm{CRH})$ triggers jejunal mast cell and eosinophil activation in IBS patients. Gastroenterology 2004;126(suppl 2):A38.

165. Ventura MT, Polimeno L, Amoruso AC, et al. Intestinal permeability in patients with adverse reactions to food. Dig Liver Dis 2006;38:732-736.

166. Ozdemir O, Arrey-Mensah A, Sorensen RU. Development of multiple food allergies in children taking tacrolimus after heart and liver transplantation. Pediatr Transplant 2006;10:380-383.

167. Chen C, Wang P, Su Q, Wang S, Wang F. Myosin light chain kinase mediates intestinal barrier disruption following burn injury. $\mathrm{PloS}$ One 2012;7:e34946.

168. Costantini TW, Peterson CY, Kroll L, et al. Role of p38 MAPK in burn-induced intestinal barrier breakdown. J Surg Res 2009;156: 64-69.

169. Li Y, Guo M, Shen J, et al. Limited fluid resuscitation attenuates lung and intestine injury caused by hemorrhagic shock in rats. J Invest Surg 2014;27:81-87.

170. Vaziri ND, Yuan J, Norris K. Role of urea in intestinal barrier dys- function and disruption of epithelial tight junction in chronic kidney disease. Am J Nephrol 2013;37:1-6.

171. Bekkering P, Jafri I, van Overveld FJ, Rijkers GT. The intricate association between gut microbiota and development of type 1, type 2 and type 3 diabetes. Expert Rev Clin Immunol 2013;9:1031-1041.

172. Watts T, Berti I, Sapone A, et al. Role of the intestinal tight junction modulator zonulin in the pathogenesis of type I diabetes in BB diabetic-prone rats. Proc Natl Acad Sci USA 2005;102:2916-2921.

173. Fetissov SO, Déchelotte P. The new link between gut-brain axis and neuropsychiatric disorders. Curr Opin Clin Nutr Metab Care 2011;14:477-482.

174. Heberling CA, Dhurjati PS, Sasser M. Hypothesis for a systems connectivity model of Autism Spectrum Disorder pathogenesis: links to gut bacteria, oxidative stress, and intestinal permeability. Med Hypotheses 2013;80:264-270.

175. Rebuffat SA, Kammoun-Krichen M, Charfeddine I, Ayadi H, Bougacha-Elleuch N, Peraldi-Roux S. IL-1 $\beta$ and TSH disturb thyroid epithelium integrity in autoimmune thyroid diseases. Immunobiology 2013;218:285-291.

176. Peng SN, Zeng HH, Fu AX, Chen XW, Zhu QX. Effects of rhein on intestinal epithelial tight junction in IgA nephropathy. World J Gastroenterol 2013;19:4137-4145.

177. Giardino G, Cirillo E, Maio F, et al. Gastrointestinal involvement in patients affected with 22q11.2 deletion syndrome. Scand J Gastroenterol 2014;49:274-279.

178. Klaus DA, Motal MC, Burger-Klepp U, et al. Increased plasma zonulin in patients with sepsis. Biochem Medica 2013;23:107-111.

179. Perlman SE, Friedman S, Galea S, et al. Short-term and medium-term health effects of 9/11. Lancet 2011;378:925-934.

180. Gareau MG, Jury J, Yang PC, MacQueen G, Perdue MH. Neonatal maternal separation causes colonic dysfunction in rat pups including impaired host resistance. Pediatr Res 2006;59:83-88.

181. Keita AV, Söderholm JD, Ericson AC. Stress-induced barrier disruption of rat follicle-associated epithelium involves corticotropinreleasing hormone, acetylcholine, substance $\mathrm{P}$, and mast cells. Neurogastroenterol Motil 2010;22:770-778, e221-e222.

182. Ait-Belgnaoui A, Durand H, Cartier C, et al. Prevention of gut leakiness by a probiotic treatment leads to attenuated HPA response to an acute psychological stress in rats. Psychoneuroendocrinology 2012;37:1885-1895.

183. Hill LT, Kidson SH, Michell WL. Corticotropin-releasing factor is present in intestinal tissue of patients with gastrointestinal dysfunction following shock and abdominal surgery. Nutrition 2013; 29:650-654.

184. Wei ET, Kiang JG, Buchan P, Smith TW. Corticotropin-releasing factor inhibits neurogenic plasma extravasation in the rat paw. $\mathrm{J}$ Pharmacol Exp Ther 1986;238:783-787.

185. Wei ET, Kiang JG. Inhibition of protein exudation from the trachea by corticotropin-releasing factor. Eur J Pharmacol 1987;140:63-67.

186. Kiang JG, Wei ET. Corticotropin-releasing factor inhibits thermal injury. J Pharmacol Exp Ther 1987;243:517-520.

187. Wei ET, Serda S, Tian JQ. Protective actions of corticotropinreleasing factor on thermal injury to rat pawskin. J Pharmacol Exp Ther 1988;247:1082-1085.

188. Tian JQ, Wei ET. Acute inflammatory response of the rat pawskin to acid injury is attenuated by corticotropin-releasing factor. Drug 
Chem Toxicol 1989;12:61-66

189. Wei ET, Kiang JG. Peptides of the corticoliberin superfamily attenuate thermal and neurogenic inflammation in rat pawskin. Eur J Pharmacol 1989;168:81-86.

190. Serda SM, Wei ET. Corticotropin-releasing factor inhibits the acute inflammatory response of rat pawskin to cold injury. Cryobiology 1991;28:185-190.

191. Wei ET, Gao GC. Corticotropin-releasing factor: an inhibitor of vascular leakage in rat skeletal muscle and brain cortex after injury. Regul Pept 1991;33:93-104.

192. Gao GC, Dashwood MR, Wei ET. Corticotropin-releasing factor inhibition of substance P-induced vascular leakage in rats: possible sites of action. Peptides 1991;12:639-644.

193. Kelley DM, Lichtenstein A, Wang J, Taylor AN, Dubinett SM. Corticotropin-releasing factor reduces lipopolysaccharide-induced pulmonary vascular leak. Immunopharmacol Immunotoxicol 1994; 16:139-148.

194. Yoshihara S, Ricciardolo FL, Geppetti P, et al. Corticotropin-releasing factor inhibits antigen-induced plasma extravasation in airways. Eur J Pharmacol 1995;280:113-118.

195. Whitney TM, Wang KK, Sternbach Y, Chaklis-Haley D. Reduction of ischemic reperfusion edema with corticotropin-releasing factor (CRF) in rat hind limb replantation. Ann Plast Surg 1997;38: 416-419; discussion 419-420.

196. Theoharides TC, Singh LK, Boucher W, et al. Corticotropin-releasing hormone induces skin mast cell degranulation and increased vascular permeability, a possible explanation for its proinflammatory effects. Endocrinology 1998;139:403-413.

197. Whitney TM, Bentz ML, Johnson PC. Reduction of reperfusion injury edema with corticotropin-releasing factor (CRF): a pilot study. Microsurgery 1998;18:76-78.

198. Singh LK, Boucher W, Pang X, et al. Potent mast cell degranulation and vascular permeability triggered by urocortin through activation of corticotropin-releasing hormone receptors. J Pharmacol Exp Ther 1999;288:1349-1356.

199. Rapallino MV, Cupello A, Hydén H, Izvarina NL. Modulation by acute stress of chloride permeation across microdissected vestibular neurons membranes: different results in two rabbit strains and CRF involvement. Brain Res 2001;890:255-260.
200. Esposito P, Chandler N, Kandere K, et al. Corticotropin-releasing hormone and brain mast cells regulate blood-brain-barrier permeability induced by acute stress. J Pharmacol Exp Ther 2002;303: 1061-1066.

201. Hendryk S, Jedrzejowska-Szypulka H, Jośko J, Jarzab B, Döhler $\mathrm{KD}$. Influence of the corticotropin releasing hormone $(\mathrm{CRH})$ on the brain-blood barrier permeability in cerebral ischemia in rats. J Physiol Pharmacol 2002;53:85-94.

202. Huang M, Berry J, Kandere K, Lytinas M, Karalis K, Theoharides TC. Mast cell deficient $\mathrm{W} / \mathrm{W}^{\mathrm{v}}$ mice lack stress-induced increase in serum IL-6 levels, as well as in peripheral CRH and vascular permeability, a model of rheumatoid arthritis. Int J Immunopathol Pharmacol 2002;15:249-254.

203. Lytinas M, Kempuraj D, Huang M, Boucher W, Esposito P, Theoharides TC. Acute stress results in skin corticotropin-releasing hormone secretion, mast cell activation and vascular permeability, an effect mimicked by intradermal corticotropin-releasing hormone and inhibited by histamine-1 receptor antagonists. Int Arch Allergy Immunol 2003;130:224-231.

204. Donelan J, Boucher W, Papadopoulou N, et al. Corticotropin-releasing hormone induces skin vascular permeability through a neurotensin-dependent process. Proc Natl Acad Sci USA 2006;103: 7759-7764.

205. Wu Y, Xu Y, Zhou H, Tao J, Li S. Expression of urocortin in rat lung and its effect on pulmonary vascular permeability. J Endocrinol 2006;189:167-178.

206. Cureton EL, Ereso AQ, Victorino GP, et al. Local secretion of urocortin 1 promotes microvascular permeability during lipopolysaccharide-induced inflammation. Endocrinology 2009;150:54285437.

207. Song JP, Chen X, Yang G, Geng XR. Corticotropin releasing hormone activates $\mathrm{CD} 14+$ cells to induce endothelial barrier dysfunction. Cell Biol Int Published Online First: 17 May 2013. doi:10.1002/cbin.10133

208. Wan R, Guo R, Chen C, et al. Urocortin increased LPS-induced endothelial permeability by regulating the cadherin-catenin complex via corticotrophin-releasing hormone receptor 2. J Cell Physiol 2013;228:1295-1303. 